\title{
Tissue-specific RNA splicing generates an ankyrin-like domain that affects the dimerization and DNA-binding properties of a bHLH protein
}

\author{
Elliott S. Klein, ${ }^{1,2}$ Donna M. Simmons, ${ }^{3}$ Larry W. Swanson, ${ }^{3}$ and Michael G. Rosenfeld ${ }^{2,4}$ \\ ${ }^{4}$ Howard Hughes Medical Institute and ${ }^{2}$ University of California, San Diego, California; ${ }^{1}$ Eukaryotic Regulatory Biology \\ Program, Department and School of Medicine, La Jolla, California 92093-0648 USA; ${ }^{3}$ University of Southern California, \\ Department of Biological Sciences, Neurobiology Section, Los Angeles, California 90089-2520 USA
}

\begin{abstract}
mRNAs encoding two rat bHLH proteins, referred to as REB $\alpha$ and REB $\beta$, have been identified as alternatively spliced transcripts derived from a single genomic locus. Alternative RNA processing events result in tissue-specific differences in the ratios of these two mRNAs. Although it exhibits a highly enriched level of expression in the developing neural tube, the REB gene is expressed at variable levels in many organs of the mature animal. The REB $\alpha$ sequence contains a region characterized by a leucine heptad repeat that is situated amino-terminal of the carboxy-terminally located bHLH domain. REB $\beta$ is identical to REB $\alpha$ except for a 24-amino-acid insertion in the leucine heptad repeat that results from the inclusion of an additional 72-bp exon in the REB $\beta$ transcript. As a consequence of this insertion, REB $\beta$ exhibits a markedly diminished capacity to bind to cognate E-box-binding sites and to form homodimers and heterodimers with other members of the bHLH gene family. Analysis of the 24-amino-acid REBß-specific insert revealed that it mediates an inhibitory function and exhibits a significant degree of sequence similarity to ankyrin-like repeats. It is proposed that this tissue-specific pattern of REB RNA splicing is involved in the determination of corresponding tissue-specific combinations of heterodimeric complexes of ubiquitous and tissue-restricted bHLH proteins. Thus, REB $\alpha$ and REB $\beta$ represent a novel example of a regulated formation of an ankyrin-like domain within a bHLH protein, thereby mediating control of protein-protein interactions.
\end{abstract}

[Key Words: Transcription; bHLH protein; leucine heptad repeat; ankyrin; alternative RNA splicing]

Received June 19, 1992; revised version accepted November 16, 1992.

The rapidly growing class of transcription factors termed basic helix-loop-helix (bHLH) proteins have been implicated in transcriptional processes relating to cellular growth and developmental phenotypes. Both homo- and heterodimeric interactions between members of the bHLH family appear to be essential for DNA binding. Class-A bHLH members such as Drosophila daughterless and human E12/E47 and ITF2 (Caudy et al. 1988; Murre et al. 1989a; Henthorn et al. 1990a) are defined by virtue of their relatively ubiquitous expression (Murre et al. 1989b). Expression of class-B bHLH members such as MyoD, MRF4, mammalian achaete-scute homolog 1 (MASH1), and MASH2 (Davis et al. 1987; Rhodes and Konieczny 1989; Johnson et al. 1990) is restricted to specific cell types. Heterodimerization between class-A and myogenic class-B bHLH proteins appears to be responsible for generating muscle-specific gene expression (Lassar et al. 1991). Whereas class-B bHLH proteins bind E-box motifs extremely poorly, their interaction with class-A bHLH proteins results in heterodimeric complexes with readily detectable DNA-binding activity
(Murre et al. 1989b). Therefore, control of the interaction between class-B and class-A bHLH proteins not only should have direct consequences on DNA binding but the control of gene expression and, ultimately, the regulation of developmental phenotypes.

The basic and HLH domains of both class-A and -B bHLH proteins have been demonstrated to be responsible for DNA binding and dimerization, respectively (Murre et al. 1989a; Benezra et al. 1990; Davis et al. 1990; Voronova and Baltimore 1990; Brennan et al. 1991|. Dimerization is mediated by the amphipathic helices of the HLH domains resulting in alignment of the adjoining basic regions into a bipartite DNA-binding domain. Interestingly, a third domain characterized by a leucine heptad repeat or zipper (ZIP) is often found in bHLH proteins. Mutagenesis of similar ZIP domains in the basic leucine zipper (bZIP) class of proteins, exemplified by c-Fos, c-Jun, CCAAT/enhancer-binding protein $(\mathrm{C} / \mathrm{EBP})$, and thyrotroph embryonic factor (TEF) (Kouzarides and Ziff 1988; Gentz et al. 1989; Landschulz et al. 1989; Turner and Tjian 1989; Drolet et al. 1991), 
has demonstrated such leucine heptad repeats to be essential for dimerization. The bHLH proteins upstream stimulatory factor (USF), TFE3, AP-4, c-Myc, and Max (Beckmann and Kadesch 1991; Gregor et al. 1990; Y.F. Hu et al. 1990; Blackwood and Eisenman 1991) contain ZIP domains immediately carboxy-terminal to their bHLH domains and, as such, have been grouped into a bHLH-ZIP subfamily. Mutational analyses of these bHLH-ZIP proteins have indicated that these zipper domains function in concert with the HLH domain to mediate efficient dimerization as well as to confer dimerization specificity. In the case of the ubiquitously expressed bHLH proteins E12/E47 (Murre et al. 1989a), ITF-2 (Henthorn et al. 1990b), and rat Pan-1/Pan-2 (Nelson et al. 1990), there is no zipper motif closely associated with the bHLH domain. However, leucine heptad repeats have been noted for both E12/E47, as well as Pan-1/Pan-2, and can be found in ITF-2 as well. The location of these putative zipper domains is relatively conserved ( 124-163 amino acids) with regard to their positions relative to their carboxy-terminally located bHLH domains. The function of these putative dimerization domains in these molecules has yet to be investigated.

Our interest in neuroendocrine gene expression led us to investigate the possibility that $\mathrm{HLH}$ proteins play a role in the expression of the rat calcitonin/CGRP gene. Expression of this gene is modified by tissue-specific alternative RNA splicing that results in the production of the neuropeptide CGRP in the brain and peripheral nervous system and the hormone calcitonin in the C cells of the thyroid (Amara et al. 1982; Rosenfeld et al. 1983). Previous work in this and other laboratories has identified an enhancer region situated $\sim 1 \mathrm{~kb}$ upstream of the calcitonin/CGRP start site of transcription (Peleg et al. 1990; Stolarsky-Fredman et al. 1990). Within this 174-bp region resides several putative elements that have substantial homology to the previously described E-box consensus-binding sites (Church et al. 1985; Ephrussi et al. 1985). One of these elements, located at position - 1041 to -1035 , is called the CE- 2 site. This element accounts for much of the activity of the calcitonin/CGRP enhancer that we detect in transfection analyses in neural crest-derived cells (F. Hedjran, unpubl.). We therefore sought to define neuroendocrine-expressed bHLH proteins that could potentially regulate the calcitonin/ CGRP gene expressed via a degenerate polymerase chain reaction (PCR) approach.

We have identified two new bHLH family members that represent class-A molecules based on their widespread pattern of expression in adult tissues. Analysis of their expression during embryogenesis demonstrates a particular enrichment in neuronal structures. These cDNAs appear to encode rat homologs of the recently described human E-box-binding protein HEB (Hu et al. 19921; we therefore designate them as rat E-box-binding proteins REB $\alpha$ and REB $\beta$. The deduced amino acid sequence of REB $\alpha$ exhibits a centrally located leucine heptad repeat. REB $\beta$ is identical to REB $\alpha$ except for the presence of a 24-amino-acid insertion that alters the period- icity of the leucine heptad repeat. REB $\alpha$ and $R E B \beta$ exhibit striking differences in their efficiency of DNAbinding and dimerization properties. Although the expression of both forms is widespread, we show that the alternative RNA processing responsible for their generation is regulated, resulting in a tissue-specific ratio of $\mathrm{REB} \alpha / \mathrm{REB} \beta$ mRNAs. We demonstrate that the 24amino-acid domain specific to REB $\beta$ mediates an inhibitory effect on DNA binding. Unlike the inhibitory domain demonstrated to be responsible for the distinct DNA-binding properties of E12 and E47 (Sun and Baltimore 1991), we show that the REB inhibitory domain functions to regulate dimerization. The inhibitory domain has a considerable degree of amino acid similarity with previously described ankyrin-like domains. Mechanisms of how the REB $\beta$ inhibitory domain may act to modulate the dimerization and DNA-binding properties of the REB bHLH proteins are discussed.

\section{Results \\ Cloning of $R E B \alpha$ and $R E B \beta$}

Degenerate oligonucleotides were designed that correspond to regions of amino acid identity between the bHLH domains of Pan-1, Pan-2, and daughterless (see Materials and methods). These degenerate oligonucleotides were used to amplify cDNAs derived from rat brain, trigeminal ganglion, pituitary, and CA77 cell line RNAs. DNA sequence analysis of the amplified cDNAs from these four sources indicated them to be identical and to encode a unique HLH domain with striking similarity to rat Pan-1/Pan-2 and human E12/E47 HLH domains. The degree of similarity at the deduced amino acid level ranged from $84 \%$ (human E47) to $97 \%$ (rat Pan-21, although comparison at the level of DNA indicated this cDNA to be a unique gene $182 \%$ and $75 \%$ similarity compared with rat Pan-2 and Pan-1, respectively). A rat pituitary $\lambda Z A P$ library $\left(5 \times 10^{5}\right.$ recombinants) was screened with a nondegenerate oligonucleotide corresponding to helix 1 of the deduced HLH domain encoded by the above PCR products (see Materials and methods). Fifteen independent cDNAs were isolated. Sequencing of these cDNAs allowed their grouping into three distinct but related classes diagramed in Figure $2 \mathrm{~A}$, below. REB $\alpha$ contains an open reading frame encoding a 604-amino-acid polypeptide with two distinct motifs: a bHLH domain situated near the carboxyl terminus and a centrally located L-M-L-L heptad repeat. With one exception, the amino acid sequence of this leucine heptad motif adheres to the three-four rule specifying a hydrophobic core of a coiled-coil structure (J.C. Hu et al. 1990). The amino acid sequence of REB $\alpha$ is $95 \%$ conserved compared with the recently described human E-box-binding protein $\mathrm{HEB}$ ( $\mathrm{Hu}$ et al. 1992). Within the above leucine heptad repeat and bHLH motifs, REB $\alpha$ and HEB are $100 \%$ conserved at the amino acid level and $92 \%$ conserved at the level of DNA. We therefore conclude that REB $\alpha$ is the rat homolog of human HEB. Comparison of rat REB $\alpha$ with rat Pan-1 and Pan-2 (Nelson et 
al. 1990) demonstrates both the amino acid sequence and the relative positions of the leucine repeat sequence and bHLH domains to be highly conserved. Representing the second class of cDNAs, REB $\beta$ is identical to REB $\alpha$ except for the addition of a 72-bp DNA domain that is inserted in-frame with the REB $\alpha$ polypeptide sequence (solid box in Fig. 2A, below). Insertion of this mini-exon results in the increase of the periodicity of the first heptad repeat of the leucine repeat sequence domain from 7 to 31 residues. The superimposed open reading frames and deduced amino acid sequences of $\operatorname{REB} \alpha$ and $\mathrm{REB} \beta$ are shown in Figure 1. The mini-exon of REB $\beta$ is indicated by the sequence within the solid box and, as such, is absent in REB $\alpha$. The leucine and methionine residues denoting the affected leucine repeat sequence domain are enclosed in the solid circles.

A third class of cDNA (p15, Fig. 2A) also was isolated, which diverges at the same residue as REB $\beta$ does from $\mathrm{REB} \alpha$. Clone p15 contains a truncated open reading frame, beginning with the CAG codon of glutamine 344 (Glu-344), encoding the identical carboxy-terminal region of the $\mathrm{REB} \alpha / \mathrm{REB} \beta$ polypeptides. DNA sequence analysis of clone p15 demonstrated the REB $\beta$ mini-exon to be situated $900 \mathrm{bp}$ upstream of the p15 open reading frame. As shown in Figure $2 B$, the mini-exon of REB $\beta$ [lysine 319 (Lys-319) through glutamic acid 342 (Glu-

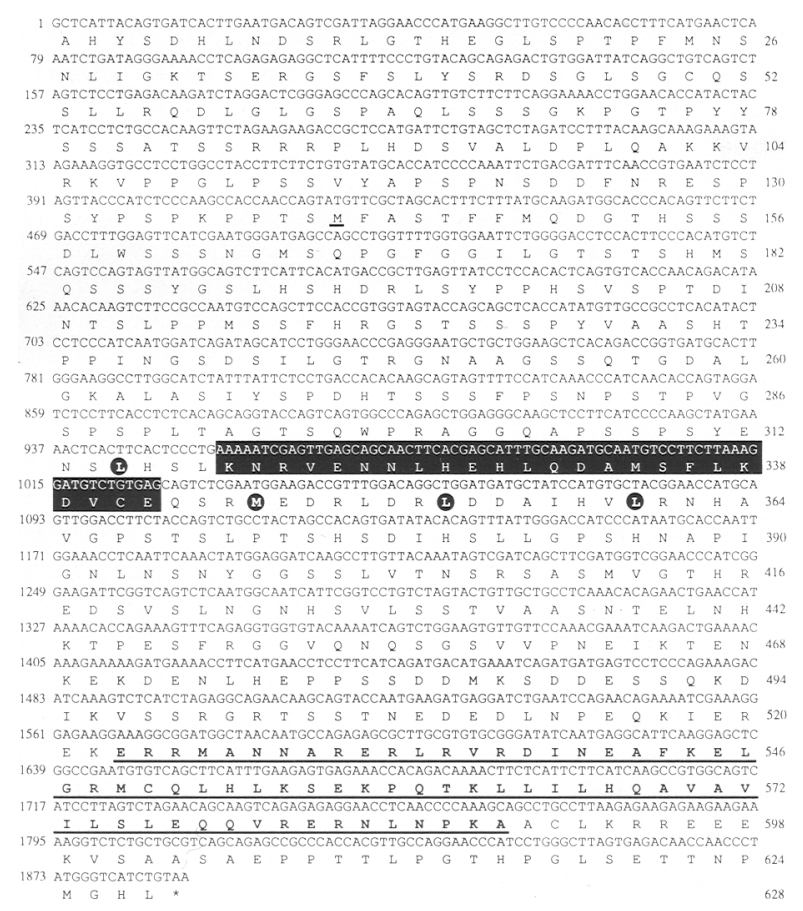

Figure 1. Nucleotide and deduced amino acid sequences of REB $\alpha$ and REB $\beta$. The sequences within the solid box (Lys-319 to Glu-342) correspond to the mini-exon present in REB $\beta$, which is absent in REB $\alpha$. Amino acid residues within the solid circles represent the leucine heptad repeat of REB $\alpha$. The underlined bold amino acid sequence corresponds to the bHLH domain The underlined Met-141 residue indicates the site of initiation utilized for in vitro translation of REB $\alpha$ and REB $\beta$ polypeptides.

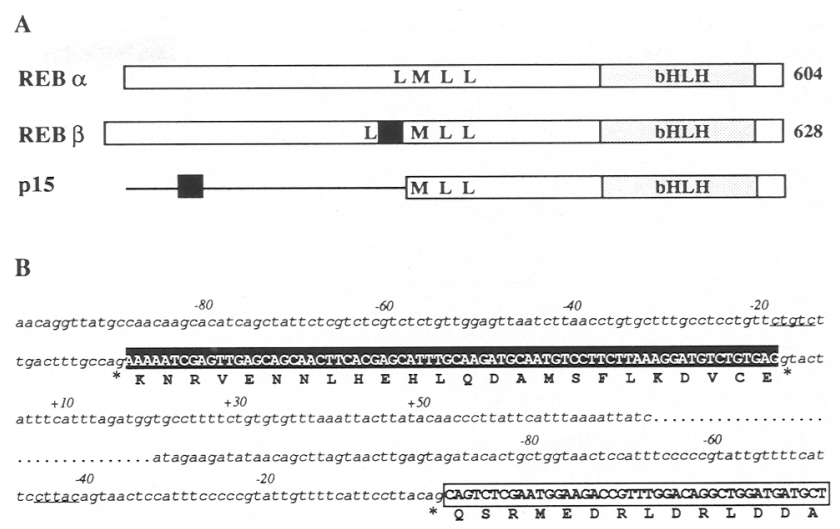

Figure 2. REB $\alpha$ and REB $\beta$ arise from alternative RNA processing. $(A)$ Schematic representation of cDNA clones REB $\alpha, R E B \beta$, and $\mathrm{p} 15$. The bHLH domains are denoted by the stippled rectangle, and the leucine heptad repeat by the sequence LMLL. The mini-exon of REB $\beta$ is represented by the solid box. The line in p15 indicates intronic sequences. $(B)$ Analysis of the genomic DNA sequence surrounding the REB $\beta$ mini-exon. The nucleotide sequences within the solid box correspond to the miniexon specific to REB $\beta$. Nucleotide sequences in the open box represent coding sequence common to both REB $\alpha$ and REB $\beta$. Consensus AG and GT splice donor and acceptor dinucleotides are indicated by asterisks ("). Potential branchpoint consensus sequences are underlined. Numbers above the nucleotide sequence denote distance (in bp) from the intron/exon splice junctions. The dotted line represents the remainder of intronic sequences.

342)] is flanked by consensus AG and GT intron splice acceptor and donor dinucleotides, respectively (for review, see Padgett et al. 1986; Green 1991). Likewise, the intron-exon splice junction immediately upstream of Gln-343 exhibits a consensus splice acceptor AG dinucleotide. The $3^{\prime}$ end of both introns contains characteristic polypyrimidine tracts (Mount 1982; Reed 1989) that have also been demonstrated to be associated with splice acceptor sequences. Furthermore, potential branchpoint consensus sequences (Reed and Maniatis 1988; Zhuang et al. 1989) are identifiable in both introns. The genomic structure containing the mini-exon of the REB $\alpha / R E B \beta$ gene was confirmed by PCR analysis of rat genomic DNA (data not shown). RNase protection analysis of RNAs from a variety of tissues failed to reveal expression of such a partially spliced transcript (data not shown). We conclude that clone p15 is a cDNA that is fortuitously derived from a partially spliced RNA transcript, demonstrating the 72-bp difference between REB $\alpha$ and REB $\beta$ cDNAs to be the result of alternative RNA processing.

\section{Expression of $R E B \alpha$ and $R E B \beta$ is regulated by tissue-specific RNA processing}

To determine the pattern of REB gene expression, Northern blot analysis was performed on poly $(A)^{+}$RNA isolated from several rat tissues. As shown in Figure $3 \mathrm{~A}$, a random-primed fragment common to both $\mathrm{REB} \alpha$ and 
Klein et al.
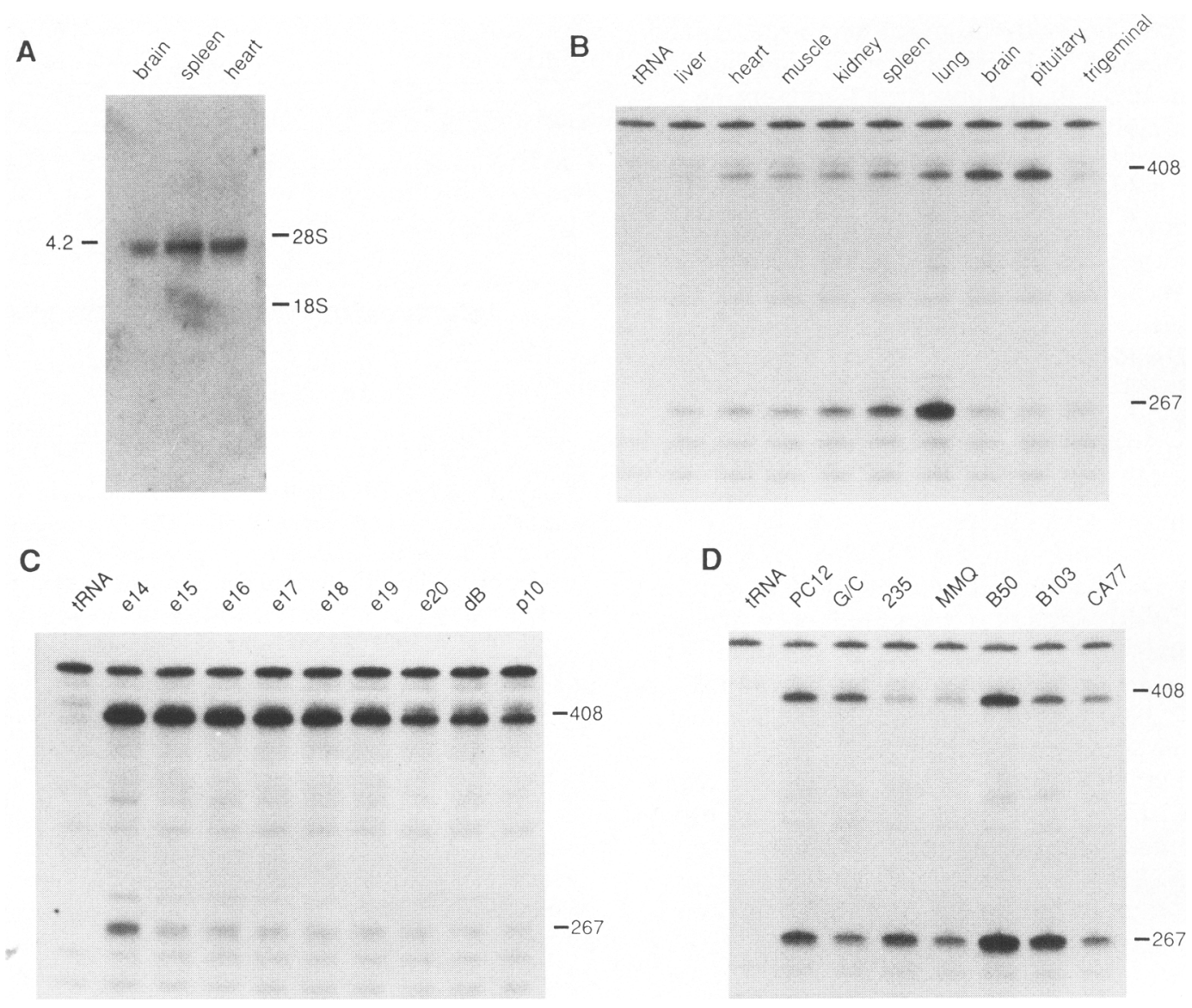

Figure 3. Alternative processing of REB $\alpha$ and REB $\beta$ RNAs is regulated in a tissue-specific manner. $(A)$ Northern analysis of REB RNAs. A cDNA fragment common to both REB $\alpha$ and REB $\beta$ was utilized to detect REB expression in RNA isolated from brain, heart, and spleen of 3-week-old rats. The migrations of REB and 18S and 28S RNAs are indicated. $(B)$ RNase protection analysis of REB $\alpha$ and REB $\beta$ transcripts in total RNA (10 $\mu$ g) isolated from tissue as indicated at the top of each lane (tRNA, yeast transfer RNA). [408 and 267 (bp)| The length of REB 3 - and REB $\alpha$-specific protected fragments, respectively. The band present in all lanes, migrating above the REB $\beta$ 408-bp band, is residual full-length probe. $(C)$ RNase protection analysis of REB $\alpha$ and REB $\beta$ transcripts in total RNA (10 $\mu$ ) isolated from embryonic rat head. (e14) Embryonic day 14; $(\mathrm{dB})$ date of birth; (p10) 10 days after birth. $(D)$ RNase protection analysis of REB $\alpha$ and REB $\beta$ transcripts in total RNA $(10 \mu \mathrm{g})$ isolated from rat cultured cell lines as indicated. Quantitation analyses of these results were performed on a Molecular Dynamics PhosphorImager.

REB $\beta$ cDNAs detects an RNA species migrating at $4.2 \mathrm{~kb}$ in adult rat brain, spleen, and heart. The abundance of this message is similar in these tissues. Given the very small difference in size (72 bp) between REB $\alpha$ and REB $\beta$ cDNAs, an RNase protection assay was utilized to allow differentiation of REB $\alpha$ and REB $\beta$ transcripts. We used an antisense REB $\beta$ RNA probe specific to nucleotides 885-1293 (see Fig. 1). Hybridization of this probe with REB $\beta$ transcripts results in full-length protection $(408$ bp). In contrast, $\mathrm{REB} \alpha$ transcripts generate a partially protected fragment of $267 \mathrm{bp}$. As shown in Figure 3B, both REB $\alpha$ - and REB $\beta$-specific protection can be detected in all of the tissues analyzed. However, the relative abundance of these two RNAs varies between the different RNAs analyzed. REB $\alpha$ is highly expressed in lung, kidney, and spleen and is expressed at reduced levels in heart, muscle, liver, pituitary, brain, and the trigeminal ganglion. REB $\beta$ expression predominates over REB $\alpha$ ex- pression in pituitary and brain. The variation in the ratio of $R E B \alpha / R E B \beta$ in these tissues (Table 1) indicates that the alternative processing responsible for the generation of these two RNAs is regulated in a tissue-specific manner.

Analysis of rat head RNA from embryonic day 14 (e14) through neonatal day 10 (p10) demonstrates a distinct difference in the relative levels of $\operatorname{REB} \alpha$ and REB $\beta$ expression (Fig. $3 \mathrm{C}$ ). Whereas the abundance of REB $\beta$ transcripts predominate over those of REB $\alpha$, the levels of both species exhibit a general decrease with continuing embryonic development. The decrease in REB $\alpha$ RNA levels is initially more precipitous during this time course, whereas that of REB $\beta$ is more gradual. Thus, the ratio between these two transcripts varies from $34 \%: 66 \%(\alpha / \beta)$ at $\mathrm{e} 14$; increases to $26 \%: 74 \%$ by e 18 , and decreases to $36 \%: 64 \%$ by p10 after birth. These results are in agreement with similar analysis of whole 
Table 1. Tissue-specific ratios of $R E B \alpha / R E B \beta$

\begin{tabular}{llll}
\hline$\alpha \geqslant \beta$ & $\alpha / \beta$ & $\alpha<\beta$ & $\alpha / \beta$ \\
\hline Lung & $80: 20$ & brain & $40: 60$ \\
Spleen & $69: 31$ & pituitary & $35: 65$ \\
Kidney & $67: 33$ & el4 head & $34: 66$ \\
Liver & $60: 40$ & e16 head & $28: 72$ \\
Muscle & $57: 43$ & e18 head & $26: 74$ \\
Heart & $51: 49$ & e20 head & $30: 70$ \\
Trigeminal & $50: 50$ & p10 head & $36: 64$ \\
\hline
\end{tabular}

The relative abundance of REB $\alpha$ and REB $\beta$ RNAs is expressed as a ratio $(\%)$ within a given tissue. Quantitation of RNase protection analyses was performed using a Molecular Dynamics PhosphorImager and includes correction for different specific activities for these two RNAs based on their relative uridine context.

adult rat brain (see Fig. 3B), which demonstrates a predominance of REB $\beta$ transcripts over REB $\alpha$ transcripts (60\%: $40 \%$, respectively).

Similar analysis of RNA isolated from a variety of immortalized rat tissue culture cell lines (Fig. 3D) again demonstrated the abundance of these two transcripts relative to each other to be variable. Rat medullary thyroid carcinoma CA77 (Muszynski et al. 1983), pheochromocytoma PC12 (Greene and Tischler 1976), and rat brainderived B50 and B103 (Schubert et al. 1974) cell lines exhibited a splice choice favoring REB $\alpha$ expression, which ranged from $62 \%: 38 \%(\alpha / \beta)$ to $74 \%: 26 \%(\alpha / \beta)$. Although the B50 and B103 cells have been characterized as neuronal by several criteria, the splice pattern of $\operatorname{REB} \alpha / \operatorname{REB} \beta$ in these cells is essentially opposite that determined for adult brain. The significance of this fact is not yet clear. Surprisingly, analysis of rat pituitaryderived cell lines demonstrated a cell type variation of splice choice. Both MMQ (Judd et al. 1988) and 235 (Reymond et al. 1984) cell lines, which have been suggested to exhibit a lactotroph phenotype, produce predominately REB $\alpha$ transcripts over REB $\beta$ transcripts with an $\alpha / \beta$ ratio of $73 \%: 27 \%$ and $79 \%: 21 \%$, respectively. In contrast, almost equivalent levels of REB $\alpha$ and REB $\beta$ transcripts $(56 \%: 44 \%)$ are expressed in the somatomammotroph cell line G/C (Bancroft 1981). Therefore, although it appears that alternative splicing results in tissue-specific ratios of REB $\alpha / \operatorname{REB} \beta$, the formal possibility exists that different cell types within a given tissue may also exhibit different levels of these two related transcripts.

To determine the spatial distribution of expression of these transcripts in the developing rat embryo and adult rat brain, in situ hybridization was performed using a radiolabeled REB antisense RNA probe. Hybridization was observed throughout the neural tube on e11 (Fig. 4). Analysis of parasagittal sections of e14 rat (Fig. 4) demonstrated intense expression of REB transcripts throughout the neural tube with a decreasing caudal to rostral gradient. Expression was not restricted to neural structures, as moderate levels of hybridization were seen in the vertebrae, the lung, and the tongue. Hybridization within the brain 2 days postbirth (p2; Fig. 4) revealed a more restricted pattern of hybridization that is enriched in the cerebellum, the pineal gland, and, to a lesser extent, the olfactory bulb. In situ analysis performed on coronal sections of adult rat forebrain (Fig. 5) exhibited a significantly restricted pattern of enriched REB RNA expression. Strong hybridization was detected in the suprachiasmatic nuclei (SCN) of the hypothalamus (Fig. 5A), the site of endogenous circadian rhythm generation (for review, see Meijer and Rietveld 1989). In a more caudal section (Fig. $5 \mathrm{~B}$ ), expression is most readily detectable in
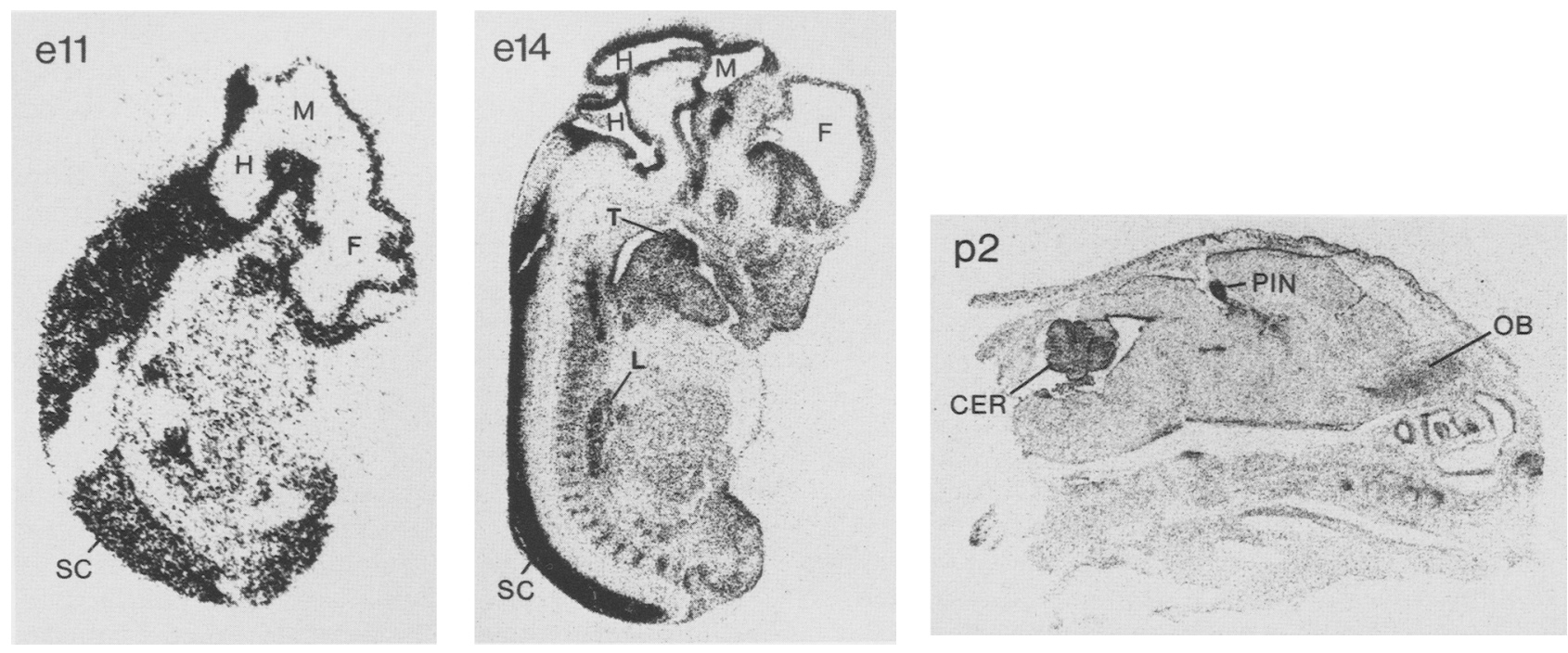

Figure 4. Expression of REB mRNA in the developing rat neural tube as determined by in situ hybridization. (el1) Autoradiograph of a parasagittal section of ell rat embryo hybridized in situ with a ${ }^{35}$ S-labeled antisense REB RNA probe. (F) Forebrain; (M) midbrain; (H) hindbrain; (SC) spinal cord. (e14) In situ hybridization of a ${ }^{35}$ S-labeled antisense REB RNA probe on e14. (L) Lung; (T) tongue. (p2) In situ analysis of REB mRNA expression within the postnatal day 2 rat head. (CER) Cerebellum; (PIN) pineal; (OB) olfactory bulb. 

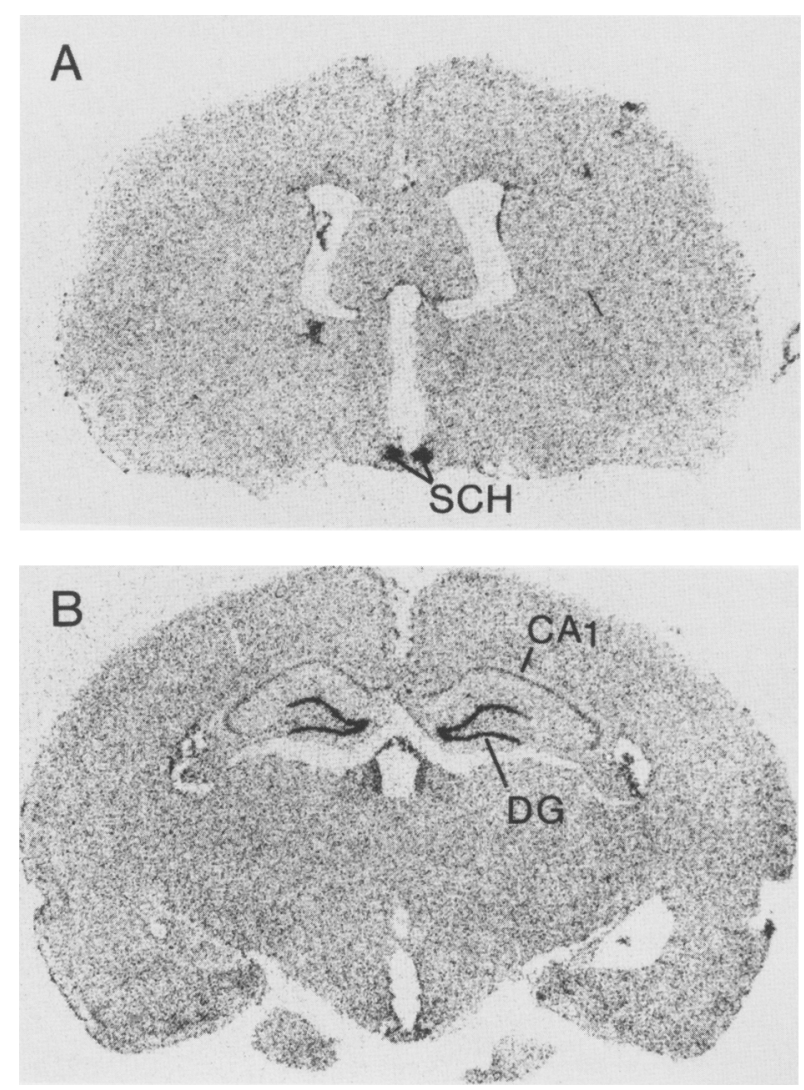

Figure 5. Restricted expression of REB mRNA in the adult rat forebrain determined by in situ hybridization. A REB ${ }^{35}$ S-labeled antisense RNA probe was used to detect REB mRNA expression in frontal sections $(A, B)$ of adult rat brain. $A$ is rostral to $B$. (SCH) Suprachiasmatic nuclei; (CAl) pyramidal layer of field $\mathrm{CAl}$ of the hippocampus; (DG) granular layer of the dentate gyrus of the hippocampus.

two parts of the hippocampus: the granular layer of the dentate gyrus (DG) and the pyramidal layer of field CAl (CA1). Because there was not an effective antisense RNA probe that would be selective for REB $\alpha$ and REB $\beta$, we cannot at this time distinguish these two forms of REB RNA in these analyses. On the basis of our RNase protection results, however, we would predict that these in situ hybridization signals reflect detection of both REB $\alpha$ and REB $\beta$ transcripts.

\section{$R E B \alpha$ and $R E B \beta$ differ in their dimerization, DNA- binding, and trans-activation properties}

We sought to determine the DNA-binding characteristics of REB $\alpha$ and REB $\beta$ using a $\kappa E-2$ box (Murre et al. 1989a)-binding motif, as well as the CE-2 box residing in the calcitonin/CGRP enhancer /see Materials and methods|. Because of the relatively poor expression of REB $\alpha$ and REB $\beta$ in vitro translation products that initiated at methionine 24 (see Fig. 1), we used in vitro-translated $\mathrm{REB} \alpha$ and REB $\beta$ polypeptides that initiated at methionine 141 (see Materials and methods) for these and sub- sequent experiments. However, use of the longer in vitro-translated products gave similar results qualitatively (data not shown). As shown in Figure 6A, in vitrotranslated REB $\alpha$ bound both E-box elements with a slight preference for the $\mathrm{KE}-2$ box in electrophoretic mobility-shift assays (EMSAs). In contrast, REB $\beta$ binding to both sites was extremely weak but detectable with longer exposure (data not shown). The complex indicated by the open arrowhead (Fig. 6A) was formed by unprogrammed reticulocyte lysate (see Fig. 8A, below; lane labeled lysate) and is most likely the result of endogenous USF activity (Gregor et al. 1990; Blackwood and Eisenman 1991 and references therein). As a control, $\left[{ }^{35} \mathrm{~S}\right]$ methionine-labeled in vitro-translated proteins are shown (Fig. 6B), demonstrating that equivalent amounts of protein were added to each binding assay. The mobility of these REB $\alpha$ and REB $\beta$ polypeptides, as demonstrated by SDS-PAGE, agrees well with predicted molecular masses of 50.3 and $53.1 \mathrm{kD}$, respectively. Thus, alteration of a domain distinct from that responsible for DNA binding (i.e., the presence of the mini-exon in $\mathrm{REB} \beta$ ) results in a polypeptide with reduced ability to bind DNA. EMSA using a fully degenerate DNA-binding site ( 16 consecutive residues) indicated the same distinction in DNA binding between REB $\alpha$ and REB $\beta$ (data not shown). We therefore conclude that the reduced ability of REB $\beta$ to bind DNA is a general, rather than a sitespecific, characteristic.

The dimerization properties of REB $\alpha$ and REB $\beta$ in solution were analyzed using glutaraldehyde cross-linking. In vitro-translated $\left[{ }^{35} \mathrm{~S}\right]$ methionine-labeled proteins were incubated in the absence or presence of $0.001 \%$ glutaraldehyde for increasing periods of time. As shown in Figure 6C, REB $\alpha$ homodimers could be visualized in the presence of glutaraldehyde, migrating at a size consistent with a homodimer $(100 \mathrm{kD})$. REB $\beta$ homodimers are only barely detectable after 40 min of glutaraldehyde crosslinking, whereas REB $\alpha$ homodimers are easily detectable after only $20 \mathrm{~min}$. Thus, alteration of the REB leucine repeat sequence domain results in two different bHLH proteins with distinct dimerization properties.

We investigated whether REB $\alpha$ and $R E B \beta$ had distinct transcriptional activation activities by DNA-mediated transfection assays. cDNA fragments containing the coding sequences for REB $\alpha$ and REB $\beta$ (amino acids 1-604 and $1-628$, respectively/ were inserted into the mammalian expression vector pCMV1 (Ingraham et al. 1990). The resulting plasmids cytomegalovirus (CMV)-REB $\alpha$ and CMV-REB $\beta$ were cotransfected into mouse C3H10T1/2 fibroblast cells with a reporter plasmid containing the rat calcitonin/CGRP enhancer element fused immediately upstream of the rat prolactin core promoter and firefly luciferase gene $(-36 \mathrm{Cal}$; see Materials and methods). As shown in Figure 7A, cotransfection of CMV-REB $\alpha$ led to an induction of luciferase activity (6.1-fold) while cotransfection of CMV-REB $\beta$ resulted in an induction that was weaker (1.8-fold). Similar experiments were performed using the luciferase reporter plasmid $4 \times$ CE-2, which contains four copies of a synthetic oligonucleotide of the calcitonin/CGRP CE-2 site fused 
A

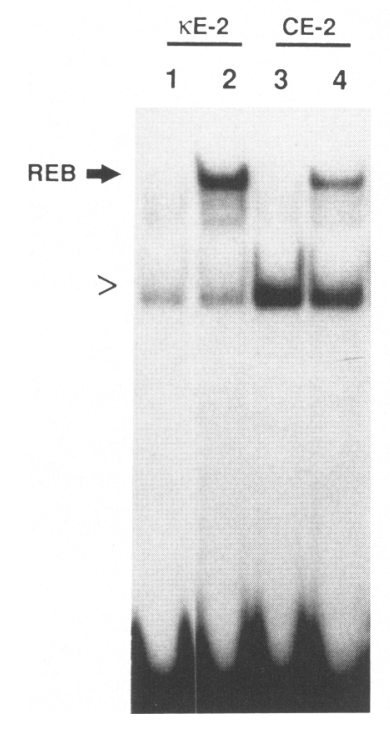

B

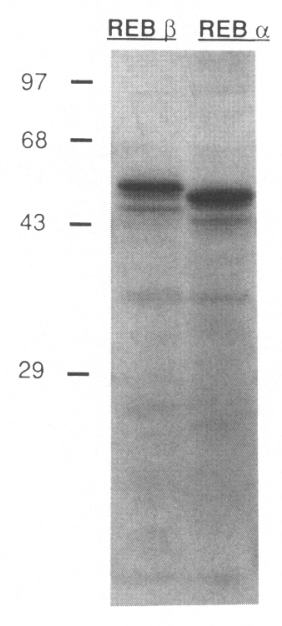

C

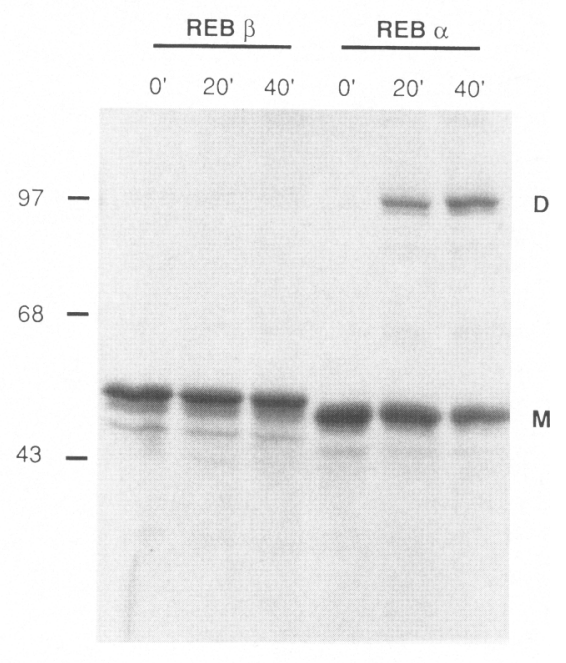

Figure 6. REB $\alpha$ and REB $\beta$ differ in their DNA-binding and dimerization properties. (A) EMSA analysis of in vitro-translated REB $\alpha-141$ and REB $\beta-141$ using both a $\kappa E-2$ site and a CE-2 site (see Materials and methods). (Lanes 1,3) REB $\beta$; (lanes 2,4) REB $\alpha$. The solid arrow indicates the migration of REB/DNA complexes. The open arrowhead indicates the complex resulting from USF contained in the reticulocyte lysates (Blackwood and Eisenman 1991). (B) SDS-PAGE analysis of in vitro-translated REB $\alpha$ - 141 and REB $\beta-141$. Two microliters of a 25- $\mu$ l translation reaction was loaded per lane. Molecular mass standards are indicated. $(C)$ Glutaraldehyde crosslinking of REB $\alpha-141$ and REB $\beta-141$. Two microliters of programmed lysate was treated with $0.001 \%$ glutaraldehyde in a final volume of $40 \mu \mathrm{l}$ for the length of time indicated. Molecular mass standards are indicated. (M and D) Monomer and dimer, respectively.

upstream of the prolactin core promoter (Fig. 7B). Cotransfection of $4 \times$ CE-2 with either CMV-REB $\alpha$ and CMV-REB $\beta$ was performed over a range of three different concentrations of expression plasmid $(1.0,2.5$, and $5.0 \mu \mathrm{g})$ in African green monkey kidney $(\mathrm{CV}-1)$ cells. The trans-activation mediated by CMV-REB $\alpha$ and CMVREB $\beta$ was dependent on these CE- 2 elements, as cotransfection of a reporter plasmid lacking these elements (pTAQ-36; see Materials and methods) failed to respond to either CMV-REB $\alpha$ or CMV-REB $\beta$ (data not shown). At all three concentrations of expression vectors used, $\mathrm{CMV}-\mathrm{REB} \alpha$ mediated a more robust trans-activation than did CMV-REB $\beta$ ( $\sim$ twofold). These transfection results extend the correlation of DNA binding and dimerization to the transcriptional activation abilities of REB $\alpha$ and REB $\beta$. REB $\alpha$ associates with itself as a homodimer and binds DNA more effectively than REB $\beta$ and is also more effective in mediating transcriptional trans-activation through a site shown for it to bind in vitro.

In vitro heterodimerization of $R E B \alpha$ and $R E B \beta$ with other $b H L H$ proteins is modulated by the miniexon encoded domain

Both in vitro (Murre et al. 1989b; Benezra et al. 1990; Weintraub et al. 1991) and in vivo (Lassar et al. 1991) analyses, as well as Drosophila genetic analyses (Ellis et al. 1990; Parkhurst et al. 1990; Erickson and Cline 1991), have led to a model of HLH protein action in which heteromeric interactions are a central theme. Because of the widespread expression of REB $\alpha$ and REB $\beta$ transcripts, we sought to demonstrate their interaction with several different cell type-restricted bHLH family members. Because REB $\alpha$ and REB $\beta$ are expressed in skeletal muscle, we examined their interaction with MRF4. In addition, expression of REB $\alpha$ and REB $\beta$ in PC- 12 cells led us to analyze their interaction with MASH1 and MASH2, which are expressed predominately in neural crest derived cells of the sympathoadrenal lineage (Johnson et al. 1990; Lo et al. 1991). Finally, owing to the apparent overlap of expression of these RNAs in the developing rat embryo, we examined the interaction of REB $\alpha$ and REB $\beta$ with the recently described bHLH protein NSCL (Begley et al. 1992). Results of in situ hybridization analysis of NSCL in the developing mouse embryo bear a striking resemblance to our results obtained for REB $\alpha$ and REB $\beta$ (e14; Fig. 4). We performed EMSA using reticulocyte lysates programmed with various bHLH RNAs (Fig. 8A). The probe used in these experiments is the rat calcitonin/CGRP CE-2 motif. Similar results were obtained using a $\mathrm{kE}-2$ probe (data not shown). The mixing of programmed lysates containing MRF4, MASH1, MASH2, or NSCL with REB $\alpha$ programmed lysate led to the appearance of a new heterodimeric species that migrated more rapidly than REB $\alpha$ homodimeric complexes in all cases. Similar results were obtained with MyoD programmed 
A

Figure 7. Comparison of $\operatorname{REB} \alpha$ and $R E B \beta$ in transient cotransfection analyses. (A) Plasmids $-36 \mathrm{Cal}$ (5 $\mu \mathrm{g} /$ three $60-\mathrm{mm}$ plates) and CMVREB $\alpha$ or CMV-REB $\beta$ (5 $\mu \mathrm{g} /$ three 60 -mm plates) were cotransfected into mouse C3H10T1/2 fibroblasts as described in Materials and methods. Fold induction of luciferase activity, standardized to $45 \mu \mathrm{g}$ of cellular protein, was calculated via comparison of base-line activity resulting from cotransfection with the plasmid pCMV1 (see Materials and methods) and is the average of triplicate determinations ( \pm S.E.M.). Similar results were obtained in three independent experiments. $(B)$ Various amounts $($ in $\mu \mathrm{g} /$ three $60-\mathrm{mm}$ plates as indicated on the $y$-axis) of either CMV-REB $\alpha$ or CMV-REB $\beta$ were cotransfected with the reporter plasmid $4 \times$ CE-2 (10 $\mu \mathrm{g} /$ three $60-\mathrm{mm}$ plates $)$ into CV-1 cells. Expression plasmid concentration was balanced to a total of $5 \mu \mathrm{g}$ of CMV-based plasmid using the plasmid pCMV1. Fold induction of luciferase activity, standardized to $45 \mu \mathrm{g}$ of cellular protein, was calculated via comparison of base-line activity resulting from cotransfection with the plasmid pCMV1 (see Materials and methods) and is the average of triplicate determinations ( \pm S.E.M.). Similar results were obtained in three independent experiments.

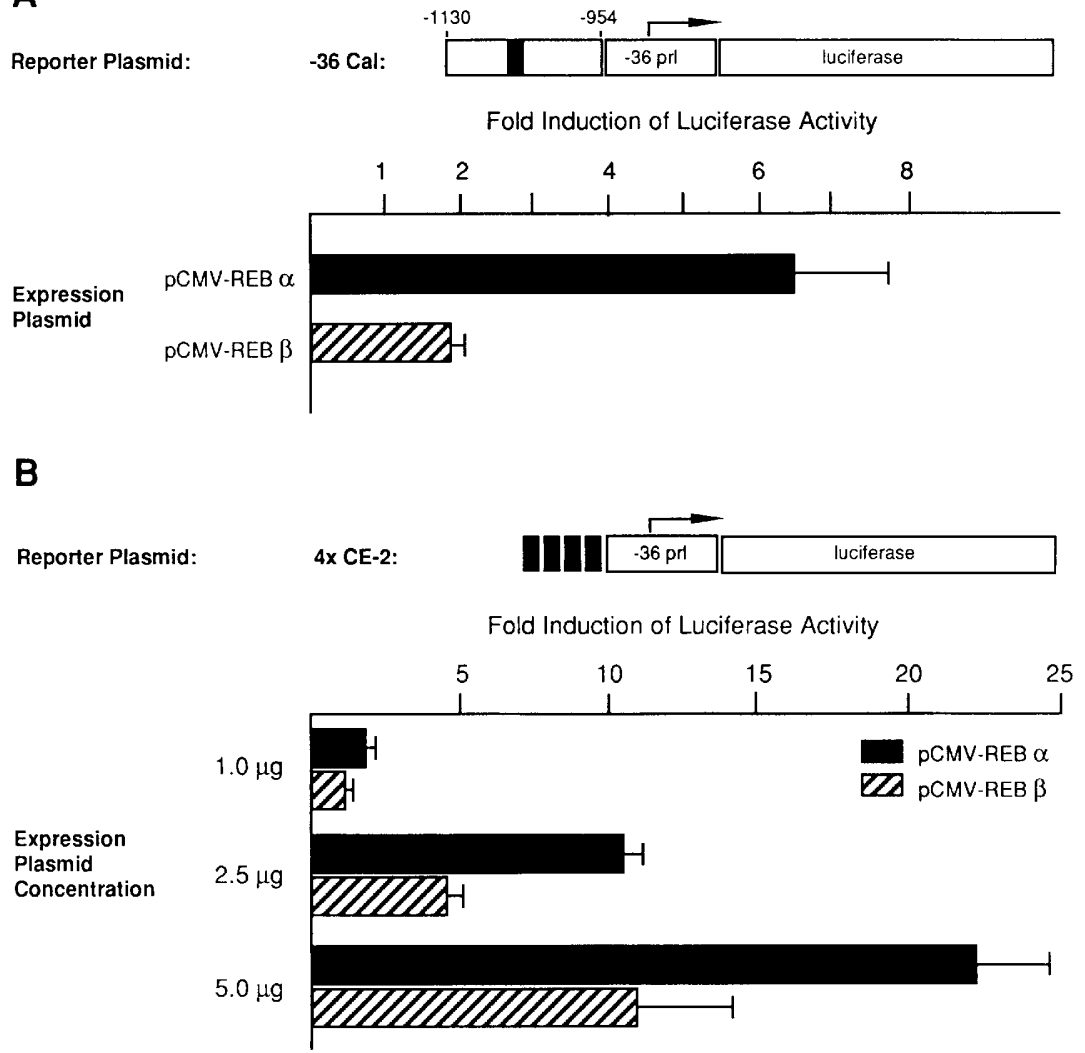

lysate (data not shown). Detection of these heterodimeric species required warming of the mixed in vitro-translated reticulocyte lysates. In contrast, mixing of these cell type-specific bHLH proteins with REB $\beta$ programmed lysate led to the formation of intermediate heterodimeric complexes that were significantly reduced in their abundance as compared with those formed with REB $\alpha$. The fold reduction in DNA binding of REB $\beta$ versus REB $\alpha$ heterodimers ranged from 5.3-fold for MRF4 to 3.8-fold for MASH2. Therefore, although REB 3 is capable of interacting with these various class-B bHLH molecules, it is less effective in forming heterodimeric/DNA complexes.

The reduced effectiveness of REB $\beta$ in forming heterodimeric/DNA complexes was analyzed further by assessing the dissociation rate of DNA-bound heterodimeric complexes using EMSA to compare the affinity of such heterodimers for DNA to those containing REB $\alpha$. MRF4 programmed reticulocyte lysate was mixed with lysates programmed with either REB $\beta$ or REB $\alpha$. After preincubation, binding reactions were challenged with a 500-fold excess of cold competitor probe, and aliquots of the reaction were subjected to EMSA after increasing durations of competitor challenge. As shown in Figure $8 \mathrm{~B}$, competition with cold $\mathrm{CE}-2$ probe over a period of 10 min indicates that the off rate of REB $\beta / M R F 4$ complexes is essentially equivalent to that of REB $\alpha$ / MRF4. These results imply that the reduced DNA binding of REB $\beta / M R F 4$ heterodimers is not caused by an al- tered affinity for DNA as compared with REB $\alpha /$ MRF4 dimers but by an altered amount of heterodimer available to bind DNA. We investigated this possibility by glutaraldehyde-mediated cross-linking of cotranslated REB $\beta / M R F 4$ and REB $\alpha / M R F 4$ (Fig. $8 \mathrm{C}$ ). After $30 \mathrm{~min}$ of glutaraldehyde treatment, reactions were subjected to SDS-PAGE. For comparison purposes, in vitro-translated $\mathrm{REB} \alpha$ was cross-linked (lane h), giving rise to a dimeric species of the expected size $(100 \mathrm{kD})$. In contrast, glutaraldehyde treatment of cotranslated REB $\alpha /$ MRF4 results in the appearance of a new protein species with an expected molecular mass of $82 \mathrm{kD}$ and the disappearance of the REB $\alpha$ homodimer species (lane d). Analysis of glutaraldehyde-treated cotranslated REB $\beta / M R F 4$ (lane b) demonstrated the appearance of the expected $85-\mathrm{kD}$ cross-linked species. The abundance of this heterodimeric species, however, is reduced (three- to fourfold) relative to that obtained for cotranslated REB $\alpha$ / MRF4. Therefore, alteration of the leucine repeat sequence in REB $\beta$ results in a bHLH protein with reduced capacity for heterodimeric and homodimeric interactions.

\section{The 24-amino-acid insert of REB $\beta$ functions as an inhibitory domain}

The dimerization and DNA-binding properties of REB $\alpha$ and REB $\beta$ are in sharp contrast. One hypothesis for this 
A
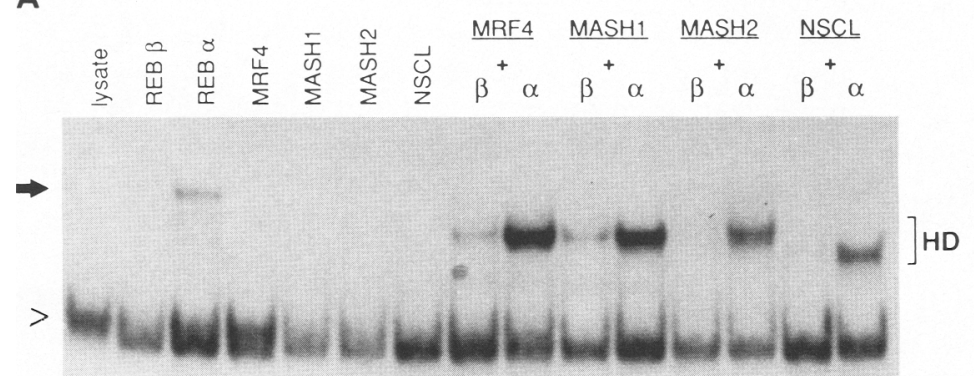

C
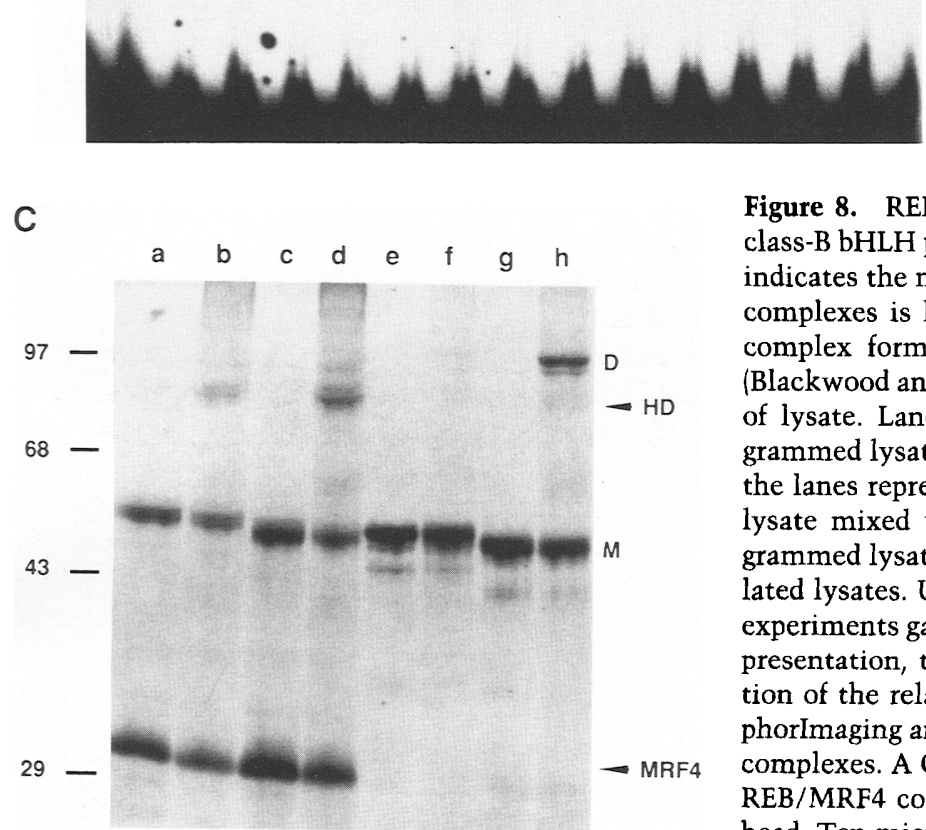

B

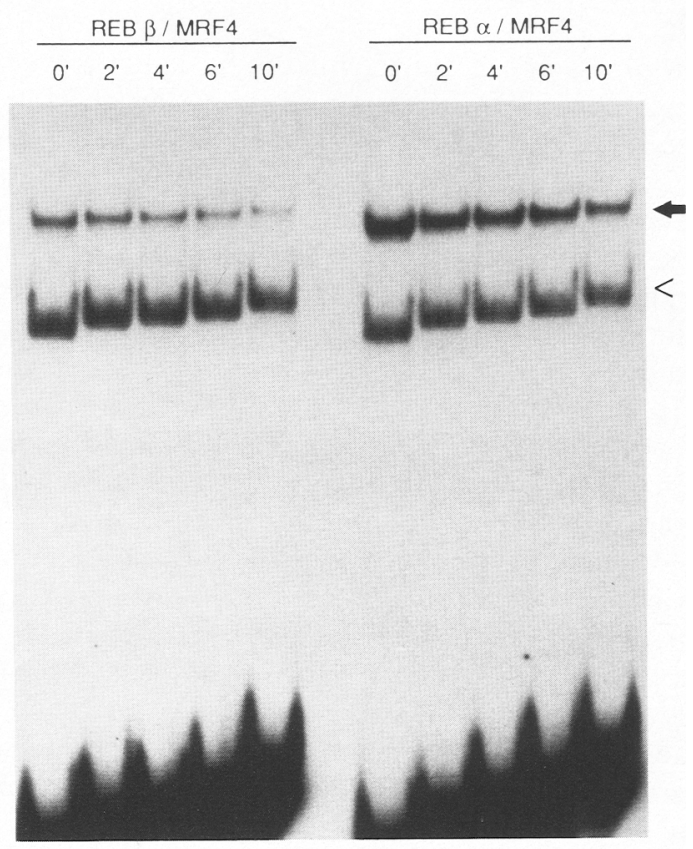

Figure 8. REB $\alpha$ and REB $\beta$ differ in their ability to dimerize with various class-B bHLH proteins. (A) EMSA analysis using a CE-2 site. The solid arrow indicates the migration of REB $\alpha / D N A$ complex. Migration of heterodimeric complexes is highlighted by a bracket. The open arrowhead indicates the complex formed by USF activity endogenous to the reticulocyte lysate (Blackwood and Eisenmann 1991). Binding reactions contained a total of $4 \mu \mathrm{l}$ of lysate. Lanes REB $\beta$ through NSCL contain $2 \mu$ l of the indicated programmed lysate mixed with $2 \mu \mathrm{l}$ of unprogrammed lysate. The remainder of the lanes represent $2 \mu \mathrm{l}$ of the indicated class-B bHLH protein programmed lysate mixed with $2 \mu$ l of either REB $\beta-141(+\beta)$ or $\operatorname{REB} \alpha-141(+\alpha)$ programmed lysate. Lanes NSCL $+\beta$ and NSCL $+\alpha$ contained $4 \mu$ l of cotranslated lysates. Utilization of mixed NSCL/REB programmed lysates in these experiments gave the same result, qualitatively; although for the purposes of presentation, the results using cotranslated products are shown. Quantitation of the relative abundance of these complexes was performed by PhosphorImaging analysis. $(B)$ Dissociation analysis of REB/MRF4 heterodimeric complexes. A CE- 2 site was used. The solid arrow indicates the migration of REB/MRF4 complexes. The USF complex is denoted with the open arrowhead. Ten microliters of MRF4 programmed lysate was mixed with $10 \mu \mathrm{l}$ of lysate programmed with either REB $\beta-141$ or REB $\alpha-141$ in a total volume of $90 \mu l$ for 45 min at $37^{\circ} \mathrm{C}$. A 500 -fold molar excess of unlabeled CE-2 site was added, and $15-\mu$ l aliquots were removed and subjected to EMSA. Duration of competition is indicated in minutes above each lane. (C) Glutaraldehyde treatment of MRF4/REB $\beta$ and MRF4/REB $\alpha$ cotranslation products. Two microliters of cotranslated MRF4 + REB $\beta-141$ (lanes $a, b)$ and $2 \mu$ lof MRF4 + REB $\alpha-141$ (lanes $c, d$ ) were treated with $0.001 \%$ glutaraldehyde for 30 $\min ($ lanes $b, d$ ). In vitro-translated REB $\beta-141$ (lanes $e, f$ ) and REB $\alpha-141$ (lanes $g, h$ ) were treated with $0.001 \%$ glutaraldehyde $($ lanes $f, h$ ). Quantitation of the species was determined by PhosphorImaging analysis. The relative mobilities of the REB $\alpha$ dimer (D), REB/MRF4 heterodimers (HD), REB monomers (M), and MRF4 are indicated.

differential behavior invokes a model whereby the uninterrupted leucine repeat sequence of REB $\alpha$ functions as a dimerization domain. This domain would be required, in addition to the HLH domain, for efficient homomeric association as has been described for other HLH proteins (Gregor et al. 1990; Beckmann and Kadesch 1991; Roman et al. 1992). Consequently, disruption of such a pu- tative dimerization interface in REB $\beta$ would lead to its apparently weakened dimerization and DNA-binding properties. Alternatively, the 24-amino-acid insert of REB $\beta$ may not represent a disruption per se but rather the inclusion, or completion, of an inhibitory domain. This domain would function to alter the tertiary structure of REB $\beta$ such that dimerization and DNA binding 
would be significantly compromised relative to the $\alpha$ form.

To assess the requirement of the leucine repeat sequence domain for efficient dimerization of $\operatorname{REB} \alpha$, leucines 315 and 329 (Leu-315 and Leu-329; L1 and L3 of the leucine repeat, respectively) were mutated to proline residues individually and in combination. As shown in Figure 9A, substitution of a proline residue for L1 (lane 4), L3 (lane 5), or L1 and L3 (lane 6) did not result in the inhibition of $R E B \alpha$ binding to the CE- 2 site. A reciprocal mutation of REB $\beta$ was made, whereby the last four residues of the 24-amino-acid insert (DVCE) were mutated to LHSL, reconstituting the REB $\alpha$ leucine repeat sequence. As shown in Figure 9A, lane 7, this REBß (LHSL) mutant did not result in measurable DNA binding. Analysis of the dimerization properties of these REB mutants was performed using glutaraldehyde cross-linking (Fig. 9B). Without exception, readily detectable dimer formation correlated directly with measurable DNA-binding activity.

Inspection of the primary amino acid sequence of the 24-amino-acid insert of REB $\beta$ reveals it to contain a variety of charged as well as hydrophobic residues. Similarly, the unaltered leucine repeat sequence domain of $\mathrm{REB} \alpha$ also exhibits a marked charged and hydrophobic nature. Application of Chou-Fasman algorithms (Chou and Fasman 1974) to the REB $\alpha$ primary sequence predicts an $\alpha$-helical potential to be located throughout the leucine repeat sequence of $\mathrm{REB} \alpha$ (Fig. 10A). Likewise, the REB $\beta$-specific insertion exhibits a helical potential (represented by the hatched domain in Fig. 10A). Such a putative structure would result in the extension of $\alpha$-helical domain of the leucine repeat sequence. The plotting of both of these helical structures on a helical spiral /data not shown) demonstrates the amphipathic nature of these putative domains.

As mutagenesis of the putative zipper domain of REB $\alpha$ (above) did not lead to inhibition of REB $\alpha$ DNA-binding and cross-linking capability, the role of the mini-exonencoded insert in the inhibition of REB $\beta$ DNA binding was assessed by site-directed mutagenesis. To that end, two mutations were made. Similar to that made for $\mathrm{REB} \alpha(\mathrm{L} 3 \rightarrow \mathrm{P})$, the analogous leucine residue (Leu-353) of REB $\beta$ was mutated to a proline. In addition, Leu-326 and Leu-330 were, in combination, mutated to prolines $[\operatorname{REB} \beta(2 \mathrm{~L} \rightarrow \mathrm{P})]$. As shown in Figure 9D (lanes 5,6$)$, the $\mathrm{REB} \beta(\mathrm{L} 3 \rightarrow \mathrm{P})$ mutant, in contrast to wild type (lanes 3,4 , exhibits a small degree of cross-linking in solution. Furthermore, the $\operatorname{REB} \beta(2 \mathrm{~L} \rightarrow \mathrm{P})$ mutant exhibits significant cross-linking capability (lanes 7,8$)$. Correlating with the ability of these mutants to dimerize in solution is their capabilty to bind DNA (Fig. 9C, lanes 4,5). Therefore, rather than mediating a neccessary dimerization interface, the leucine repeat sequence appears to be part of a larger domain in the context of the $\beta$ form of REB. This domain would be predicted to exhibit a helical conformation. The consequence of acquisition of this domain in REB $\beta$, mediated by alternative RNA splicing, is the inhibition of the dimerization and DNA-binding capabilities of the REB $\beta$ molecule. We therefore refer to this domain as a helical inhibitory domain (HID) and approximate its location within the REB $\beta$ molecule to be at least from Leu-326 to Leu-356. One motif that has been implicated in protein-protein interactions for several classes of cellular proteins has been the so-called ankyrin-like repeats (for review, see Blank et al. 1992). Comparison of a variety of such ankyrin repeats with the REB $\beta$ HID reveals a considerable degree of sequence similarity over a 28-amino-acid region (Fig. 10B). Of interest with regard to the above mutation analysis of REB $\beta$ are Leu-326 and Leu-356, which are highly conserved among the ankyrin-like repeats included in the comparison. The mechanism by which the HID may mediate its inhibitory role in the REB $\beta$ molecule is discussed below.

\section{Discussion}

In this paper we describe the cloning and characterization of mRNAs encoding two E-box-binding proteins, $\mathrm{REB} \alpha$ and REB $\beta$. Although REB transcripts are widely expressed, we found that their abundance levels within adult tissues varied greatly. Comparison of $\operatorname{REB} \alpha$ to human HEB (Hu et al. 1992) indicates that REB $\alpha$ lacks $\sim 80$ amino-terminal residues but exhibits a $95 \%$ identity at the amino acid level over the remainder of the molecule. As such, REB $\alpha$ is likely to represent the rat homolog of HEB. Of the 30 nonconserved amino acid residues in $\mathrm{REB} \alpha, 17$ are located in a region between the leucine repeat sequence and the $\mathrm{A}$ domain (Sun and Baltimore 1991) immediately amino-terminal of the bHLH domain. The degree of conservation throughout the remainder of the molecule would suggest the apparent importance of the structure of this $\mathrm{E}$ protein, given that other class-A bHLH proteins can apparently serve the same function: Several widely expressed bHLH proteins have now been shown to interact with tissue-specific bHLH proteins in vitro (Murre et al. 1989a; Hsu et al. 1991; Hu et al. 1992; Lin et al. 1991; Johnson et al. 1992). Furthermore, Lassar et al. (1991) have demonstrated interactions in vivo between MyoD and myogenin with E12/E47-like proteins and have indicated the necessity of such heterodimeric interactions for myogenic conversion of $\mathrm{C} 3 \mathrm{H} 10 \mathrm{~T} 1 / 2 \mathrm{fi}$ broblasts. Thus, one level of regulation expected to affect the heteromeric combinations with tissue-specific bHLH proteins is the the different relative concentrations of REB and other ubiquitously expressed bHLH proteins.

$\mathrm{REB} \alpha$ and $\mathrm{REB} \beta$ can trans-activate luciferase reporter constructs under the regulation of the rat calcitonin/ CGRP enhancer, as well as the multimerized E box (CE2) from the calcitonin/CGRP enhancer. However, in consideration of the widespread expression of REB mRNAs in the tissues analyzed, it is clear that REB $\alpha$ or REB $\beta$ is not sufficient for expression of the calcitonin/ CGRP gene, which is limited to subpopulations of neural and neural crest-derived cells (Amara et al. 1982; Rosenfeld et al. 1983). Given the evidence for heterodimeric interactions between different bHLH proteins in vivo (Lassar et al. 1991), it is quite likely that tissue-specific calcitonin/CGRP enhancer function uti- 


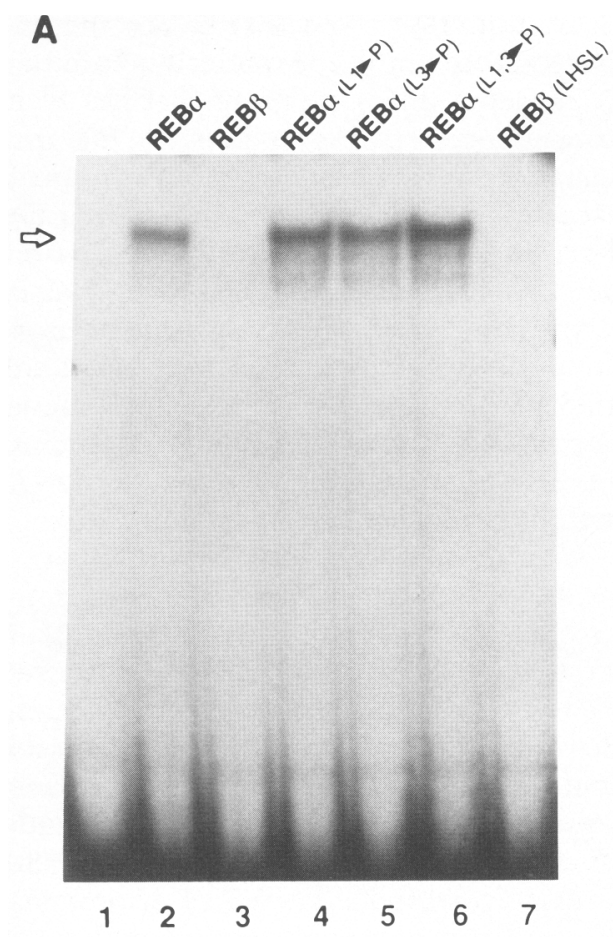

\section{B}
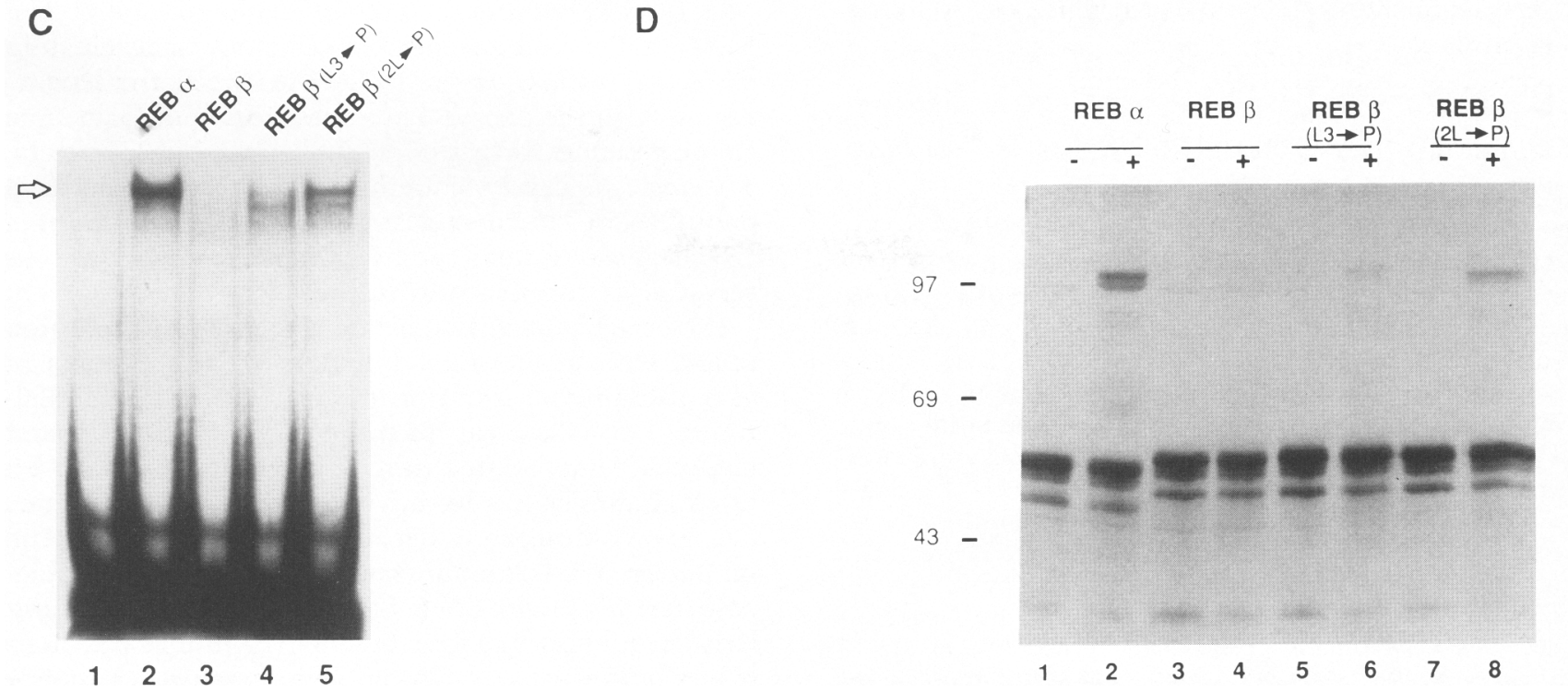

Figure 9. The 24-amino-acid insert of REB $\beta$ functions as an inhibitory domain. (A) EMSA analysis of in vitro-translated REB $\alpha$ mutants using a CE-2 site probe. The open arrow indicates the migration of the REB/DNA complexes. (Lane 1) Unprogrammed lysate; (lanes 2-7) programmed lysates as indicated at the top of each lane. Mutated amino acids are indicated in parentheses. (B) Glutaraldehyde cross-linking analysis of $\mathrm{REB} \alpha$ mutants. The relative migration of molecular mass standards is indicated as are monomers (M) and dimers (D). Lanes labeled with a + represent the addition of $0.001 \%$ glutaraldehyde. Specific mutations are indicated at the top of each lane. (C) EMSA analysis of in vitro-translated REB $\beta$ mutants using a CE-2 site probe. (Lane 1) Unprogrammed lysate; (lanes 2-5) lysates programmed as indicated at the top of each lane. $(D)$ Glutaraldehyde cross-linking analysis of REB $\beta$ mutants as indicated in the parenthesis at the top of each lane.

lizes a class-A bHLH protein in conjunction with a tissue-specific class- $B$ partner.

Expression of REB $\alpha / R E B \beta$ RNA is highly enriched throughout the entire neural tube during embryogenesis. Expression of these RNAs in the neural tube on e14 ap- pears to be quite similar for that obtained for the bHLH protein NSCL (Begley et al. 1992). Thus, the REB/NSCL heterodimeric complex may be of particular interest regarding control of developmental pathways in the nervous system. In contrast to that of the developing em- 


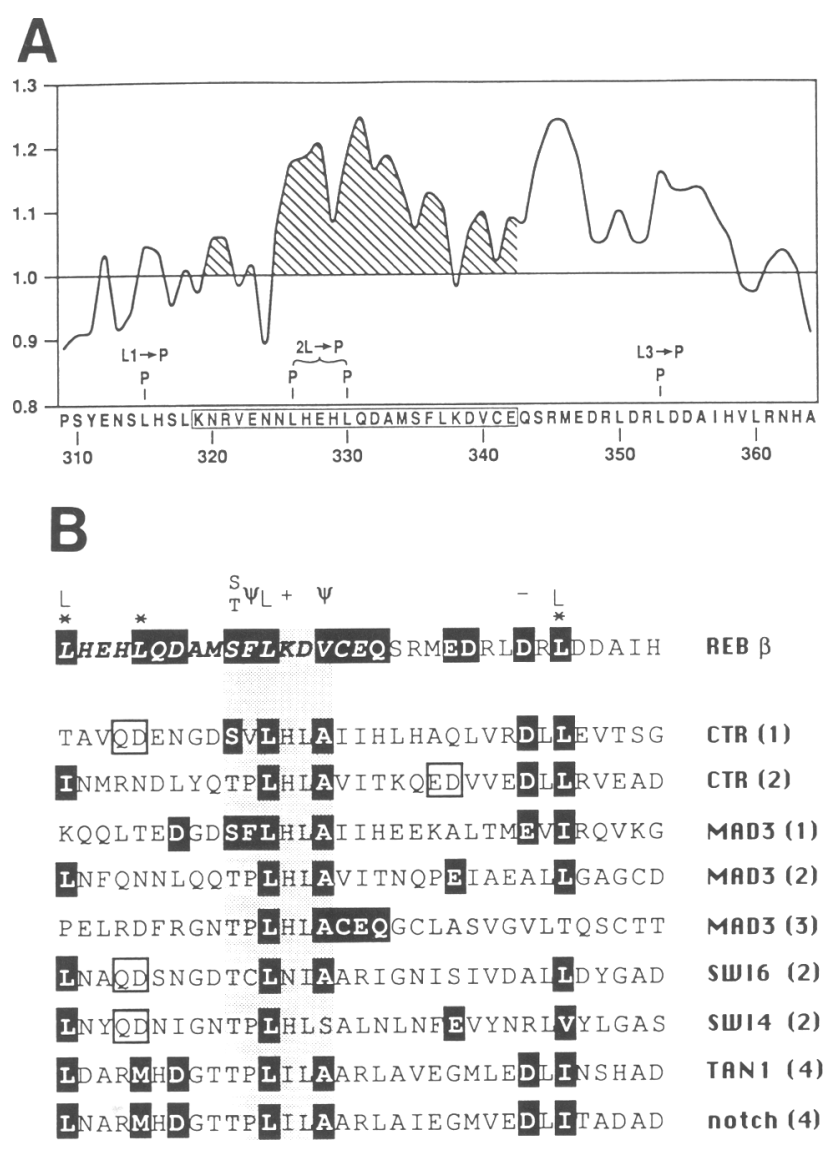

Figure 10. Analysis of the REB $\beta$ HID. (A) A helical potential predicted by the Chou-Fasman algorithms (Chou and Fasman 1974) is shown for the HID of REB $\beta$. Numbers and single letter amino acid code along the $x$-axis indicate the relative position in the REB $\beta$ molecule. The hatched area beneath the curve represents the $\alpha$-helical potential of the 24-amino-acid insert whose amino acid sequence is boxed. Locations of leucine to proline mutations are indicated. $(B)$ Comparison of the amino acid sequence of the REB $\beta$ HID with various ankyrin-like repeats. The core ankyrin TPLHLA motif is located in the shaded box. Identical residues as well as conservative substitutions are indicated by the solid boxes. The boxed QD and ED represent conserved amino acids that are out of alignment by one residue. Sequences used for this comparison are the ankyrin-like repeats 1 and 2 of CTR (Kieran et al. 1990), repeats 1-3 of MAD3 (Haskill et al. 1991), repeat 2 of SWI4 and SWI6 (Andrews and Herskowitz 1989), and repeat 4 of TANl and Notch (Ellisen et al. 1991). A consensus based on the similarity of these sequences is indicated above the REB $\beta$ sequence. $|\Psi\rangle,-$, and +1 Hydrophobic, acidic, and basic amino acids, respectively. Asterisks $\left({ }^{*}\right)$ indicate the location of REB $\beta$ mutations affecting the HID.

bryo, REB RNA expression in the adult forebrain is enriched in a more restricted pattern. Expression of REB in the SCN is provocative, given the evidence implicating this hypothalamic nucleus in the generation of circadian rhythms in mammals (for review, see Meijer and Rietveld 1989). Evidence exists for the regulation of AP-1 DNA-binding activity in the SCN during light entrain- ment (Kornhauser et al. 1992). Whether or not the expression of $R E B \alpha / R E B \beta$ is similarly regulated within the SCN remains to be determined.

The leucine zipper domains of several bHLH-ZIP proteins have been analyzed. In the case of AP-4 (Y.F. Hu et al. 1990|, two separate leucine repeats are required for efficient dimerization and appear to limit dimerization possibilities such that heterodimerization with E12 is restricted. Similarly, the leucine zippers of USF (Gregor et al. 1990) and TFE3 (Beckman and Kadesch 1991) are required for efficient homodimerization. Unlike these bHLH-ZIP molecules, REB $\alpha$ does not require its leucine repeat sequence for efficient dimerization and DNA binding based on our mutational analysis. Furthermore, an amino-terminal truncated form of REB $\alpha$ missing the zipper (amino acids 460-604) binds E-box elements both as a homodimer and a heterodimer with REB $\alpha, \operatorname{REB} \beta$, or Pan-1 (data not shown). Rather, the leucine repeat sequence is utilized as an inhibitory motif in conjunction with the alternatively spliced 24-amino-acid insert in the REB $\beta$ molecule. Spliced together, these two domains generate a region, the HID, of amino acid similarity with the previously described ankyrin-like repeats. The ankyrin-like repeats conserved in a variety of proteins consist of a 33-amino-acid motif containing a core TPLHLA element (for review, see Blank et al. 1992). The REB $\beta$ ankyrin-like repeat core consensus element (SFLKDV) is most similar to the MAD3 ankyrin-like repeat 1 , with the conservative substitution of lysine and valine residues for histidine and alanine, respectively. Although the degree of amino acid identity ranges from only $11 \%$ to $21 \%$ over a 28 -amino-acid region, up to a $36 \%$ degree of similarity exists when one allows for conservative amino acid substitutions.

How might the HID mediate the observed inhibition of REB DNA binding and dimerization? In the Rel class of transcription factors (for review, see Lenardo and Baltimore 1989; Baeuerle 1991) the ankyrin repeat domain has been demonstrated to mediate inhibition of NF- $\mathrm{BB}$ DNA binding by conferring interaction of I $\mathrm{KB}$ with $\mathrm{p} 65$ (i.e., in cis). Moreover, such ankyrin-like repeats mediate inhibition of DNA binding of the precurser p105 molecule in trans (Blank et al. 1991; Liou et al. 1992). Similarly, an ankyrin-like repeat domain facilitates the interaction of GAPB $\alpha$ and GAPB $\beta$ and is required for DNA binding (Thompson et al. 1991). We propose that the ankyrin-like REB $\beta$ HID interacts with another domain of the REB molecule in cis. Such an intramolecular event would render REB $\beta$ to dimerize poorly and, hence, bind DNA weakly. Analysis of the HID sequence reveals two regions of hydrophobic amino acids, Leu-326 to valine 340 (Val-340) and methionine 346 (Met-346) to Leu-360, which conform to the three-four rule (J.C. Hu et al. 1990 ), suggesting a potential role of this domain in protein-protein interactions. Although other plausible explanations exist, given the precedent of intramolecular regulation of p105 DNA binding, we predict that the HID interacts the bHLH domain of REB $\beta$. The effect of such an interaction would in effect mask the HLH domain from both homomeric and heteromeric interac- 
tions with other HLH domains. Thus, an equilibrium would exist between the interaction of the REB HLH domain with the HID (intramolecular) and with the HLH domain of another factor (intermolecular). Such a model would predict that intermolecular interactions of REB $\beta$ would be favored at relatively high protein concentrations. Using bacterially expressed REB $\beta$, DNA binding is observed, albeit at a lower efficiency than for REB $\alpha$ (data not shown). Thus, REB $\alpha$ can be visualized as an "open" conformation, with the HLH domain available for interaction, whereas in the case of REB $\beta$, a "closed" conformation would be predicted. Given the precedence for protein-protein interactions of the ankyrin-like repeat domains, we speculate that the closed conformation of REB $\beta$ may be subject to regulation perhaps by the interaction of another yet undefined molecule with the HID region.

The requirement for the several class-A bHLH molecules identified so far is not obvious, given the apparent similarity of their heterodimerization capabilities in vitro. We propose that the tissue-specific alternative splicing of the $R E B$ gene transcripts exemplifies an additional mechanism that may regulate bHLH heterodimeric combinations. The leucine repeat sequence of the $R E B$ gene is encoded on two distinct exons, rather than as a single functional domain as demonstrated for the E2A gene (Sun and Baltimore 1991). Thus, REB gene products may not be functionally redundant with respect to those of the E2A gene. The alternative splicing of the $R E B$ gene generates a striking (eightfold) tissue-specific variation in the ratio of REB $\alpha$ (HID - ) and REB $\beta$ (HID +) transcripts and would be expected to alter the distribution of heteromeric associations. Furthermore, the potential for the regulation of the dimerization and DNA binding of REB $\beta$ by the HID, either by the action of a putative regulatory factor or by a post-translational modification, would also differentiate REB gene products from those of E2A. Competition between different tissue-specific bHLH proteins for available E12/E47-like proteins has been proposed (Lassar et al. 1991) as a means whereby different developmental pathways are selected via mutual exclusion. Similarly, competition between coexpressed class-A bHLH proteins for available class-B family members could potentially result in functionally distinct dimeric combinations. We predict that in tissues (e.g., lung) that express the $R E B$ gene at high levels and exhibit a splice choice that favors REB $\alpha$ transcripts, the formation of REB-containing heteromeric complexes would be more probable relative to tissues in which the REB $\beta$ splice choice predominates, owing to a more effective competition of REB $\alpha$ with other E proteins (ITF2, E12/E47) for tissue-restricted partners. It is conceivable that these different heteromeric partners may be utilized to differentially interact with the transcriptional machinery. Whereas homodimeric species of either myogenic or E2A gene products appear not to be detectable in muscle cell extracts (Lassar et al. 1991), it remains a formal possibility that REB $\alpha$ may function as a homodimer at some stage in development and that alteration of the ratio of REB $\alpha / \operatorname{REB} \beta$ could regulate the degree of such homodimer binding.
Thus, as a consequence of both transcriptional and post-transcriptional regulation of the $R E B$ gene, it is likely that the encoded bHLH proteins exert selective roles in distinct cell types. As has been noted (Cline et al. 1989; Weintraub et al. 1991), bHLH protein dosage has been proposed to be the basis of sex-specific X chromosome to autosome ratio assessment in Drosophila (Parkhurst et al. 1990; Erickson and Cline 1991). It has been suggested that a relatively small change (twofold) in the experimentally manipulated gene dosage of sisterless $b$ via temporally early hairy gene expression accounts for abrogation of sex-specific transcription of the sex lethal gene (Parkhurst et al. 1990). The tissue-specific RNA processing that regulates REB dimerization properties by the generation of the HID region may therefore represent one example of a means by which the apparently widespread phenomenon of balancing bHLH protein levels directs distinct developmental programs.

\section{Materials and methods}

\section{PCR cloning}

Degenerate oligonucleotides representing the conserved basic (ANNARER) and helix 2 (EQQVRERN) of the bHLH domains of Pan-1, Pan-2, and daughterless (Caudy et al. 1988; Nelson et al. 1990) were used to amplify target bHLH domains. First-strand cDNA was generated using AMV reverse transcriptase (Promega) from oligo(dT)-primed poly(A) ${ }^{+}$RNA (Maniatis et al. 1982 ) isolated from rat heart, trigeminal, pituitary, brain, and the rat thyroid medullary carcinoma cell line CA77, as described previously (Chirgwin et al. 1979). PCR reactions contained $10 \mathrm{mM}$ Tris- $\mathrm{HCl}$ (pH 8.3), $50 \mathrm{mM} \mathrm{KCl}, 3 \mathrm{mM} \mathrm{MgCl}_{2}$, $0.01 \%$ gelatin, $0.25 \mathrm{~mm}$ dNTPs, $5 \mu$ l first-strand cDNA reaction, $1 \mu \mathrm{g}$ of each degenerate oligonucleotide primer, and 2 units of Taq polymerase (Perkin-Elmer Cetus) in a total volume of 100 $\mu l$. PCR reactions were performed using an Eppendorf thermocycler for 35 cycles $\left(94^{\circ} \mathrm{C}, 1 \mathrm{~min}^{\circ} 50^{\circ} \mathrm{C}, 3 \mathrm{~min} ; 72^{\circ} \mathrm{C}, 1 \mathrm{~min}\right)$. PCR reactions were analyzed by agarose gel electrophoresis, and the resulting 174-bp amplified fragments were subcloned into pBKS (Stratagene) and sequenced (Sanger et al. 1977) with Sequenase (U.S. Biochemical). A XZAP (Stratagene) pituitary library $\left(5 \times 10^{5}\right.$ recombinants) was screened with a ${ }^{32}$-labeled oligonucleotide (5'-GCAAACAATGCTCGGGAGCGCTTGC GTATG-3') corresponding to the coding strand of helix 1 of the amplified PCR fragment. One positive clone was isolated, designated p14. Double-stranded sequencing of P14 using synthetic oligonucleotide primers determined it to contain an open reading frame of $1600 \mathrm{bp}$ within the context of a 4-kb insert. In an effort to obtain full-length cDNA, two radiolabeled (Feinberg and Vogelstein 1983) PstI-SstI p14 fragments were used to rescreen the rat pituitary library resulting in the isolation of an additional 15 overlapping clones that represented three distinct cDNAs: $R E B \alpha, R E B \beta$, and $p 15$.

\section{Plasmid construction}

Expression vectors for REB $\alpha$ and REB $\beta$ were constructed via PCR introduction of a NdeI site at nucleotide position 420 (see Fig. 1) corresponding to Met-141 of both proteins. The resulting 95-bp NdeI-EcoRI fragment [nucleotide positions 420-515 (see Fig. 1)] was subcloned into a modified pET3a plasmid (Studier 
and Moffat 1986). The remainder of both cDNAs was added onto this amplified fragment via utilization of the EcoRI site at nucleotide position 515, resulting in the plasmids pETREB $\alpha$ 141 and $\mathrm{pETREB} \beta-141$. Site-directed mutagenesis of $\mathrm{pETREB} \alpha$ 141 and pETREB $\beta-141$ was performed using the procedure of Kunkel (1985). The expression plasmids CMV-REB $\alpha$ and CMVREB $\beta$ were constructed by insertion of HindIII-BamHI fragments of REB $\alpha$ and REB $\beta$ into the mammalian expression vector pCMV1 (Ingraham et al. 1990). The reporter plasmid -36Cal was constructed as follows. A PCR-generated fragment (-1102 to -982 ) of the calcitonin/CGRP enhancer (Stolarsky-Fredman et al. 1990) was inserted into the BamHI site of the reporter plasmid pTaq-36. pTaq-36 includes the rat prolactin minimal promoter $(-36$ to +34$)$ fused to the firefly luciferase gene (de Wet et al. 1987; Ingraham et al. 1988). The reporter plasmid $4 \times$ CE-2 was similarly constructed via insertion of four copies of the calcitonin/CGRP CE-2 site (see DNA-binding analyses) into the BamHI site of the plasmid pTaq-36.

\section{Northern and RNase protection analyses}

RNA was isolated (Chirgwin et al. 1979), and poly (A) ${ }^{+}$mRNA was selected, fractionated on a formaldehyde- $1 \%$ agarose denaturing gel, transferred to nitrocellulose, and hybridized (Maniatis et al. 1982) for $12 \mathrm{hr}$ with a radiolabeled probe (Feinberg and Vogelstein 1983) consisting of PstI-SstI REB $\alpha$ fragments. Blots were washed in $2 \times \mathrm{SSC}, 0.1 \% \mathrm{SDS}$, at $50^{\circ} \mathrm{C}$ for $20 \mathrm{~min}$ followed by $0.5 \times \mathrm{SSC}, 0.1 \% \mathrm{SDS}$, at $50^{\circ} \mathrm{C}$ for $20 \mathrm{~min}$. RNase protection analysis was performed as described (Ausubel et al. 1992). Briefly, the KpnI-ScaI fragment of clone REB $\beta$ (nucleotides 885 1296; Fig. 1) was subcloned into the plasmid pBKSII - (Stratagene). Following linearization with KpnI and subsequent filling in with T4 polymerase (BRL), $\left[\alpha^{32} \mathrm{P}\right] \mathrm{UTP}$-incorporated antisense RNA transcripts were generated with $\mathrm{T} 7$ polymerase (Promega). Ten micrograms of total RNA was incubated in a 30 - $\mu$ l volume containing $80 \%$ formamide, $40 \mathrm{~mm}$ PIPES (pH 6.7), $0.4 \mathrm{M} \mathrm{NaCl}$, $1 \mathrm{mM}$ EDTA, and $10^{5} \mathrm{cpm}$ of antisense radiolabeled probe for 12 hr at $45^{\circ} \mathrm{C}$. RNase A digestion $(25 \mu \mathrm{g} / \mathrm{ml})$ was carried out at $30^{\circ} \mathrm{C}$ for $45 \mathrm{~min}$ and terminated by the addition of SDS and proteinase K. After extraction with phenol/chloroform $(50: 50)$ and ethanol precipitation, samples were analyzed on a $5 \%$ acrylamide/8 $\mathrm{M}$ urea sequencing gel.

\section{In situ hybridization analyses}

Timed-pregnant Sprague-Dawley rats, as determined by vaginal plug (defined as e0), were transcardially perfused with saline and fixed with paraformaldehyde on the appropriate embryonic day, and tissues were processed as described previously (Simmons et al. 1990). In situ hybridizations were performed as described previously (Simmons et al. 1990) using ${ }^{35}$ S-labeled antisense RNA probe common to both REB $\alpha$ and REB $\beta$. The PstI-SstI fragment (nucleotides 952-1637 of REB $\alpha$; Fig. 1) was inserted into pBKSII (Stratagene) and transcribed with T7 RNA polymerase in the presence of ${ }^{35}$-labeled UTP $(1000-1500 \mathrm{Ci} / \mathrm{mmole}$; New England Nuclear). In situ hybridization studies of adult male Sprague-Dawley rat forebrain sections were performed as described previously (Simmons et al. 1989) using the same ${ }^{35} \mathrm{~S}$ labeled REB antisense RNA probe.

\section{DNA-binding assays}

Gel retardation analysis was performed with a double-stranded oligonucleotide containing the calcitonin/CGRP CE-2 site (top strand, 5'-GATCCAAAGGGGCAGCTGTGCAAATCA$3^{\prime}$; bottom strand, 5'-GATCTGATTTGCACAGCTGCCCCT-
TTG-3') or a $\mathrm{kE}-2$ site (Murre et al. 1989a). Both strands were radiolabeled using $\left[\gamma^{32} \mathrm{P}\right] \mathrm{ATP}$ and T4 polynucleotide kinase, annealed, and filled in with Klenow fragment. Double-strand probe was purified on a $10 \%$ polyacrylamide gel. Binding reactions were carried out for $30 \mathrm{~min}$ at room temperature and contained $10 \mathrm{~mm}$ Tris- $\mathrm{HCl}$ (pH 7.6), $40 \mathrm{~mm} \mathrm{NaCl}, 1 \mathrm{~mm} \mathrm{DTT}, 1 \mathrm{~mm}$ EDTA, $0.05 \mathrm{ng}$ of labeled probe, $100 \mathrm{ng}$ of poly[d(I-C)]/[d(I-C)] and between 2 and $4 \mu$ l of either unprogrammed or programmed reticulocyte lysate. Reactions were electrophoresed on a $5 \%$ polyacrylamide, $0.75 \times$ TBE nondenaturing gel. Alternatively, when programmed lysates were post-translationally mixed, binding reactions were carried out at $37^{\circ} \mathrm{C}$ for $45 \mathrm{~min}$.

\section{In vitro transcription and translation}

In vitro transcription was performed using a Stratagene in vitro transcription kit. Reactions (50 $\mu \mathrm{l}$ volume) contained $2 \mu \mathrm{g}$ of either pETREB $\alpha-141$ or pETREB $\beta-141$ and were carried out for 1 $\mathrm{hr}$ at $37^{\circ} \mathrm{C}$ using $\mathrm{T} 7 \mathrm{RNA}$ polymerase. The plasmid pBKSMRF4, generously provided by S. Konieczny (Purdue University, West Lafayette, IN), was used to transcribe MRF4 RNA using T3 RNA polymerase. Plasmids NJ1-19 and NJ2-A, kindly provided by D. Anderson (California Institute of Technology, Pasadena), were used to transcribe MASH1 and MASH2 RNAs, respectively, with T3 RNA polymerase. NSCL RNA was transcribed with T3 RNA polymerase from the plasmid pBSKNSCL (no. 2609), which was kindly provided by I. Kirsch (National Institutes of Health, Bethesda, MD|. MyoD RNA was transcribed with T7 RNA polymerase from the plasmid pVZCII $\alpha$, generously provided by H. Weintraub (Fred Hutchinson Cancer Center, Seattle, WA). In vitro translations were performed in rabbit reticulocyte lysates (Promega) as per the manufacturer's instructions in the presence of $\left[{ }^{35} \mathrm{~S}\right]$ methionine.

\section{Glutaraldehyde cross-linking analysis}

In vitro-translated proteins were subjected to glutaraldehyde treatment as described by Y.F. Hu et al. (1990). Two microliters of rabbit reticulocyte lysate containing ${ }^{35} \mathrm{~S}$-labeled in vitrotranslated proteins was incubated in $40 \mu$ l of Z-buffer $[20 \mathrm{~mm}$ HEPES (pH 7.6), $50 \mathrm{~mm} \mathrm{MgCl} 2,10 \%$ (vol/vol) glycerol, $1 \mathrm{~mm}$ EDTA, $0.1 \%$ NP-40, $1 \mathrm{~mm}$ DTT]. Treatment with $0.001 \% \mathrm{glu}-$ taraldehyde was performed at $20^{\circ} \mathrm{C}$ for either $30 \mathrm{~min}$ or the amount of time indicated in the figure legends. Reactions were terminated by the addition of SDS/ $\beta$ ME stop buffer and electrophoresed on $8 \%(\mathrm{wt} / \mathrm{vol})$ polyacrylamide-SDS gels and fluorographed after drying.

\section{DNA-mediated transfection analysis}

African green monkey kidney cells $(\mathrm{CV}-1)$ and mouse C3H10T1/2 fibroblasts were plated at a density of $9 \times 10^{4}$ cells / 60-mm plate in Dulbecco's modified Eagle medium containing $10 \%$ newborn calf serum. Cells were cotransfected with expression and reporter plasmids as indicated in the figure legends by calcium phosphate coprecipitation (Chen and Okayama 1987). Cells were harvested $48 \mathrm{hr}$ after transfection and assayed for luciferase activity as described previously (de Wet et al. 1987).

\section{Acknowledgments}

We are indebted to Dr. David Anderson for generously providing the MASH vectors, Dr. Ilan Kirsch for the NSCL vector, and Dr. Stephen Konieczny for the MRF4 vector, and Dr. Harold Weintraub for the MyoD vector. In addition, we wish to thank Simon Rhodes and Michael Wegner for careful review of the manu- 
script, Charles Nelson for assistance with tissue culture, Dan Drolet and Jeff Voss for helpful discussions, and Susan Inglis for her invaluable help in preparation of the manuscript. These studies were supported in part by a grant from the National Institutes of Health (DK39949). This work was done during the tenure of a research fellowship from the American Heart Society, California Affiliate (to E.S.K.) and this work was conducted under American Cancer Society support. M.G.R. is an investigator with the Howard Hughes Medical Institute.

The publication costs of this article were defrayed in part by payment of page charges. This article must therefore be hereby marked "advertisement" in accordance with 18 USC section 1734 solely to indicate this fact.

\section{References}

Amara, S.G., V. Jonas, M.G. Rosenfeld, I.M. Verma, and R.M. Evans. 1982. Alternative RNA processing in calcitonin gene expression generates mRNAs encoding different polypeptide products. Nature 298: 240-244.

Andrews. B.J. and I. Herskowitz. 1989. The yeast SW14 protein contains a motif present in developmental regulators and is part of a complex involved in cell-cycle-dependent transcription. Nature 342(6251): 830-833.

Ausubel, F.M., R. Brent, R.E. Kingston, D.D. Moore, J.G. Seidman, J.A. Smith, and K. Struhl, eds. 1992. Current protocols in molecular biology. Harvard Medical School, Massachusetts General Hospital, Boston, MA.

Baeuerle, P.A. 1991. The inducible transcription activator NFkappa $\mathrm{B}$; regulation by distinct protein subunits. Biochim. Biophys. Acta 1072: 63-80.

Bancroft, F.C. 1981. GH cells: Functional clonal lines of rat pituitary cells. In Functionally differentiated cell lines (ed. Gordon Sato), pp. 47-55. Liss, New York.

Beckmann, H. and T. Kadesch. 1991. The leucine zipper of TFE3 dictates helix-loop-helix dimerization specificity. Genes \& Dev. 5: 1057-1066.

Begley, C.G., S. Lipkowitz, V. Göbel, K.A. Mahon, V. Bertness, A.R. Green, N.M. Gouch, and I.R. Kirsch. 1992. Molecular characterization of NSCL, a gene encoding a helix-loop-helix protein expressed in the developing nervous system. Proc. Natl. Acad. Sci. 89: 38-42.

Benezra, R., R.L. Davis, D. Lockshon, D.L. Turner, and H. Weintraub. 1990. The protein Id: A negative regulator of helixloop-helix DNA binding proteins. Cell 61: 49-59.

Blackwood, E.M. and R.N. Eisenman. 1991. Max: A helix-loophelix zipper protein that forms a sequence-specific DNA binding complex with myc. Science 251: 1211-1217.

Blank, V., P. Kourilsky, and A. Israel. 1991. Cytoplasmic retention, DNA binding and processing of the NF- $\mathrm{kB}$ p50 precursor are controlled by a small region in its C-terminus. EMBO I. 10: 4159-4167.

- 1992. NF-кB and related proteins: Rel/dorsal homologies meet ankyrin-like repeats. Trends Biol. Sci. 17: 135140.

Brennan, T.J., T. Chakraborty, and E.N. Olson. 1991. Mutagenesis of the myogenin basic region identifies an ancient protein motif critical for activation of myogenesis. Proc. Natl. Acad. Sci. 88: 5675-5670.

Caudy, M., H. Vässin, M. Brand, R. Tuma, L.Y. Jan, and Y.N. Jan. 1988. daughterless, a Drosophila gene essential for both neurogenesis and sex determination, has sequence similarities to myc and the achaete-scute complex. Cell 55: 10611067.

Chen, C. and H. Okayama. 1987. High efficiency transforma- tion of mammalian cells by plasmid DNA. Mol. Cell. Biol. 7: 2745-2752.

Chirgwin, J.J., A.E. Przbyla, R.J. MacDonald, and R.J. Rutter. 1979. Isolation of biologically active ribonucleic acid from sources enriched in ribonuclease. Biochemistry 18: 5294 5299.

Chou, P.Y. and G.D. Fasman. 1974. Prediction of protein conformation. Biochemistry 13: 222-244.

Church, G.M., A. Ephrussi, W. Gilbert, and S. Tonegawa. 1985. Cell type specific contacts to immunoglobulin enhancers in nuclei. Nature 313: 798-801.

Cline, T.W. 1989. The affairs of daughterless and the promiscuity of developmental regulators. Cell 59: 231-234.

Davis, R.L., H. Weintraub, and A.B. Lassar. 1987. Expression of a single transfected cDNA converts fibroblasts to myoblasts. Cell 51: 987-1000.

Davis, R.L., P.F. Cheng, A.B. Lassar, and H. Weintraub. 1990. The MyoD DNA binding domain contains a recognition code for muscle-specific gene activation. Cell 60: 733-746.

de Wet, J.R., K.V. Wood, M. deLuca, D.R. Helinski, and S. Subrimani. 1987. Firefly luciferase gene: Structure and expression in mammalian cells. Mol. Cell. Biol. 7: 725-737.

Drolet, D.W., K.M. Scully, D.M. Simmons, M. Wegner, K. Chu, L.W. Swanson, and M.G. Rosenfeld. 1991. TEF, a transcription factor expressed specifically in the anterior pituitary during embryogenesis, defines a new class of leucine zipper proteins. Genes \& Dev. 5: 1739-1753.

Ellis, H.M., D.R. Spann, and J.W. Posakony. 1990. extramacrochaetae, a negative regulator of sensory organ development in Drosophila, defines a new class of helix-loop-helix proteins. Cell 61: 27-38.

Ellisen, L.W., J. Bird, D.C. West, A.L. Soreng, T.C. Reynolds, S.D. Smith, and J. Sklar. 1991. TAN-1, the human homolog of the Drosophila notch gene, is broken by chromosomal translocations in $\mathrm{T}$ lymphoblastic neoplasms. Cell 66(4): 649-661.

Ephrussi, A., G.M. Church, S. Tonegawa, and W. Gilbert. 1985. B lineage-specific interactions of an immunoglobulin enhancer with cellular factors in vivo. Science 227: 134-140.

Erickson, J.W. and T.W. Cline. 1991. Molecular nature of the Drosophila sex determination signal and its link to neurogenesis. Science 251: 1071-1074.

Feinberg, A.P. and B. Vogelstein. 1983. A technique for radiolabeling DNA restriction endonuclease fragments to high specific activity. Anal. Biochem. 132: 6-13.

Gentz, R., F.J. Rauscher III, C. Abate, and T. Curran. 1989. Parallel association of Fos and Jun leucine zippers juxtaposes DNA binding domains. Science 243: 1695-1699.

Green, M.R. 1991. Biochemical mechanisms of constitutive and regulated pre mRNA splicing. Annu. Rev. Cell Biol. 7: 550599.

Greene, L.A. and A.S. Tischler. 1976. Establishment of a noradrenergic clonal line of rat adrenal pheochromocytoma cells which respond to nerve growth factor. Cell Biol. 73: 2424 2428.

Gregor, P.D., M. Sawadogo, and R.G. Roeder. 1990. The adenovirus major late transcription factor USF is a member of the helix-loop-helix group of regulatory proteins and binds to DNA as a dimer. Genes \& Dev. 4: 1730-1740.

Haskill, S., A.A. Beg, S.M. Tompkins, J.S. Morris, A.D. Yurochko, A. Sampson-Johannes, K. Mondal, P. Ralph, and A.S. Baldwin Jr. 1991. Characterization of an immediate-early gene induced in adherent monocytes that encode IKB-like activity. Cell 65: 1281-1289.

Henthorn, P., M. Kiledjian, and T. Kadesch. 1990a. Two distinct transcription factors that bind the immunoglobulin en- 
hancer $\mu \mathrm{E} 5 / \kappa E 2$ motif. Science 247: 467-470.

Henthorn, P., R. McCarrick-Walmsley, and T. Kadesch. 1990b. Sequence of the cDNA encoding ITF-2, a positive-acting transcription factor. Nucleic Acids Res. 18: 677-681.

Hsu, H.L., J.T. Cheng, Q. Chen, and R. Baer. 1991. Enhancerbinding activity of the tal-1 oncoprotein in association with the E47/E12 helix-loop-helix proteins. Mol. Cell. Biol. 11: 3037-3042.

Hu, J.C., E.K. O'Shea, P.S. Kim, and R.T. Sauer. 1990. Sequence requirements for coiled-coils: Analysis with $\lambda$ repressorGCN4 leucine zipper fusions. Science 250: 1400-1403.

Hu, J.-S., E.N. Olson, and R.E. Kingston. 1992. HEB, a helixloop-helix protein related to E2A and ITF2 that can modulate the DNA binding ability of myogenic regulatory factors. Mol. Cell. Biol. 12: 1031-1042.

Hu, Y.F., B. Lüscher, A. Admon, N. Mermod, and R. Tjian. 1990. Transcription factor AP-4 contains multiple dimerization domains that regulate dimer specificity. Genes \& Dev. 4: 1741-1752.

Ingraham, H.A., R. Chen, H.J. Mangalam, H.P. Elsholtz, S.E. Flynn, C.R. Lin, D.M. Simmons, L.W. Swanson, and M.G. Rosenfeld. 1988. A tissue-specific transcription factor containing a homeodomain specifies a pituitary phenotype. Cell 55: 519-529.

Ingraham, H.A., S.E. Flynn, J.W. Voss, V.R. Albert, M.S. Kapiloff, L. Wilson, and M.G. Rosenfeld. 1990. The POU-specific domain of Pit-1 is essential for sequence-specific, high affinity DNA binding and DNA-dependent Pit-1-Pit-1 interactions. Cell 61: 1021-1033.

Johnson, J.E., S.J. Birren, and D.J. Anderson. 1990. Two rat homologues of Drosophila achaete-scute specifically expressed in neuronal precursors. Nature 346: 858-861.

Johnson, J.E., S.J. Birre, T. Saito, and D.J. Anderson. 1992. DNA binding and transcriptional regulatory activity of mammalian achaete-scute homologous (MASH) proteins revealed by interaction with a muscle-specific enhancer. Proc. Natl. Acad. Sci. 89: 3596-3600.

Judd, A.M., I.S. Login, K. Kovacs, P.C. Ross, B.L. Spangelo, W.D. Jarvis, and R.M. MacLeod. 1988. Characterization of the MMQ cell, a prolactin-secreting clonal cell line that is responsive to dopamine. Endocrinology 123: 2341-2350.

Kieran, M., V. Blank, F. Logeat, J. Vandekerckhove, F. Lottspeich, O. Le Bail, M. Urban, P. Kourilsky, P. Baeuerle, and A. Israel. 1990. The DNA binding subunit of NF- $\kappa B$ is identical to factor KBF1 and homologous to the rel oncogene product. Cell 62: 1007-1018.

Kornhauser, J.M., D.E. Nelson, K.E. Mayo, and J.S. Takahashi. 1992. Regulation of jun-B messenger RNA and AP-1 activity by light and a circadian clock. Science 255: 1581-1584.

Kouzarides, T. and E. Ziff. 1988. The role of the leucine zipper in the fos-jun interaction. Nature 336: 646-651.

Kunkel, T.A. 1985. Rapid and efficient site-specific mutagenesis without phenotypic selection. Proc. Natl. Acad. Sci. 82: 488-492.

Landschulz, W.H., P.F. Johnson, and S.L. McKnight. 1989. The DNA binding domain of the rat liver nuclear protein C/EBP is bipartite. Science 243: 1681-1688.

Lassar, A.B., R.L. Davis, W.E. Wright, T. Kadesch, C. Murre, A Voronova, D. Baltimore, and H. Weintraub. 1991. Functional activity of myogenic HLH proteins requires hetero-oligomerization with E12/E47-like proteins in vivo. Cell 66: 305315 .

Lenardo, M.J. and D. Baltimore. 1989. NF-kappa B: A pleiotropic mediator of inducible and tissue-specific gene control. Cell 58: 227-229.

Lin, H., K.E. Yutzey, and S.F. Konieczny. 1991. Muscle-specific expression of the troponin I gene requires interactions between helix-loop-helix muscle regulatory factors and ubiquitous transcription factors. Mol. Cell. Biol. 11: 267-280.

Liou, H.-C., G.P. Nolan, S. Ghosh, T. Fujita, and D. Baltimore. 1992. The NF-kB p50 precursor. pl05, contains an internal IкB-like inhibitor that preferentially inhibits p50. $E M B O J$. 11: 3003-3009.

Lo, L.-C., J.E. Johnson, C.W. Wuenschell, T. Saito, and D.J. Anderson. 1991. Mammalian achaete-scute homolog 1 is transiently expressed by spatially restricted subsets of early neuroepithelial and neural crest cells. Genes \& Dev. 5: 1524-1537.

Maniatis, T., E.F. Fritsch, and J. Sambrook. 1982. Molecular cloning: A laboratory manual. Cold Spring Harbor Laboratory, Cold Spring Harbor, New York.

Meijer, J.H. and W.J. Rietveld. 1989. Neurophysiology of the suprachiasmatic circadian pacemaker in rodents. Physiolog. Rev. 69: 671-707.

Mount, S.M. 1982. A catalogue of splice junction sequences. Nucleic Acids Res. 10: 459-472.

Murre, C., P.S. McCaw, and D. Baltimore. 1989a. A new DNA binding and dimerization motif in immunoglobulin enhancer binding, daughterless, MyoD, and myc proteins. Cell 56: $777-783$.

Murre, C., P.S. McCaw, H. Vässin, M. Caudy, L.Y. Jan, Y.N. Jan, C.V. Cabrera, J.N. Buskin, S.D. Hauschka, A.B. Lassar, H. Weintraub, and D. Baltimore. 1989b. Interactions between heterologous helix-loop-helix proteins generate complexes that bind specifically to a common DNA sequence. Cell 58: $537-544$.

Muszynski, M., R.S. Birnbaum, and B.A. Roos. 1983. Glucocorticoids stimulate the production of preprocalcitonin-derived secretory peptides by a rat medullary thyroid carcinoma cell line. J. Biol. Chem. 258: 11678-11683.

Nelson, C., L.P. Shen, A. Meister, E. Fodor, and W.J. Rutter. 1990. Pan: A transcriptional regulator that binds chymotrypsin, insulin, and AP-4 enhancer motifs. Genes \& Dev. 4: $1043-1053$

Padgett, R.A., P.J. Grabowski, M.M. Konarska, S.R. Seiler, and P.A. Sharp. 1986. Splicing of messenger RNA precursors. Annu. Rev. Biochem. 55: 1119-1150.

Parkhurst, S.M., D. Bopp, and D. Ish-Horowicz. 1990. X : a ratio, the primary sex-determining signal in Drosophila, is transduced by helix-loop-helix proteins. Cell 63: 1179-1191.

Peleg, S., R.V. Abruzzese, G.J. Cote, and R.F. Gagel. 1990. Transcription of the human calcitonin gene is mediated by a $\mathrm{C}$ cell-specific enhancer containing E-box-like elements. Mol. Endocrinol. 4: 1750-1757.

Reed, R. 1989. The organization of $3^{\prime}$ splice-site sequences in mammalian introns. Genes \& Dev. 3: 2113-2123.

Reed, R. and T. Maniatis. 1988. The role of the mammalian branchpoint sequence in pre-mRNA splicing. Genes \& Dev. 2: $1268-1276$.

Reymond, M.J., D.D. Nansel, G.H. Burrows, W.B. Neaves, and J.C. Porter. 1984. A new clonal strain of rat pituitary tumor cells: A model for non-regulated secretion of prolactin. Acta Endocrinol. 106: 459-470.

Rhodes, S.J. and S.F. Konieczny. 1989. Identification of MRF4: A new member of the muscle regulatory factor gene family. Genes \& Dev. 3: 2050-2061.

Roman, C., A.G. Matera, C. Cooper, S. Artandi, S. Blain, D.C. Ward, and K. Calame. 1992. mTFE3, an X-linked transcriptional activator containing basic helix-loop-helix and zipper domains, utilizes the zipper to stabilize both DNA binding and multimerization. Mol. Cell. Biol. 12: 817-827.

Rosenfeld, M.G., J.J. Mermod, S.G. Amara, L.W. Swanson, P.E. 
Sawchenko, J. Rivier, W.W. Vale, and R.M. Evans. 1983. Production of a novel neuropeptide encoded by the calcitonin gene via tissue-specific RNA processing. Nature 304: 129135.

Sanger, F., S. Nicklen, and A. Coulson. 1977. DNA sequencing with chain-terminating inhibitors. Proc. Natl. Acad. Sci. 74: 5463-5467.

Schubert, D., S. Heinemann, W. Carlisle, H. Tarikas, B. Kines, J. Patrick, J.H. Steinbach, W. Culp, and B.L. Brandt. 1974. Clonal cell lines from the rat central nervous system. Nature 249: 224-227.

Simmons, D.M., J.L. Arriza, and L.W. Swanson. 1989. A complete protocol for in situ hybridization of messenger RNAs in brain and other tissues with radiolabeled single-stranded RNA probes. $I$. Histotechnol. 12: 169-181.

Simmons, D.M., J.W. Voss, H.A. Ingraham, J.M. Holloway, R.S. Broide, M.G. Rosenfeld, and L.W. Swanson. 1990. Pituitary cell phenotypes involve cell-specific Pit-1 mRNA translation and synergistic interactions with other classes of transcription factors. Genes \& Dev. 4: 695-711.

Stolarsky-Fredman, L., S.E. Leff, E.S. Klein, E.B. Crenshaw, J. Yeakley, and M.G. Rosenfeld. 1990. A tissue-specific enhancer in the rat-calcitonin/CGRP gene is active in both neural and endocrine cell types. Mol. Endocrinol. 4: 497504.

Studier, F.W. and B.A. Moffat. 1986. Use of bacteriophage T7 RNA polymerase to direct selective high-level expression of cloned genes. J. Mol. Biol. 189: 137-140.

Sun, X.-H. and D. Baltimore. 1991. An inhibitory domain of E12 transcription factor prevents DNA binding in E12 homodimers but not in E12 heterodimers. Cell 64: 459-470.

Thompson, C.C., T.A. Brown, and S.L. Knight. 1991. Convergence of Ets- and notch-related structural motifs in a heteromeric DNA binding complex. Science 253(5021): 762-768.

Turner, R. and R. Tjian. 1989. Leucine repeats and an adjacent DNA binding domain mediate the formation of functional cFos-cJun heterodimers. Science 243: 1689-1694.

Voronova, A. and D. Baltimore. 1990. Mutations that disrupt DNA binding and dimer formation in the E47 helix-loophelix protein map to distinct domains. Proc. Natl. Acad. Sci. 87: 4722-4762.

Weintraub, H., R. Davis, S. Tapscott, M. Thayer, M. Krause, R. Benezra, T.K. Blackwell, D. Turner, R. Rupp, S. Hollenberg, Y. Zhuang, and A. Lassar. 1991. The myoD gene family: Nodal point during specification of the muscle cell lineage. Science 251: 761-766.

Zhuang, Y., A.M. Goldstein, and A.M. Weiner. 1989. UAC UAAC is the preferred branch site for mammalian mRNA splicing. Proc. Natl. Acad. Sci. 86: 2752-2756. 


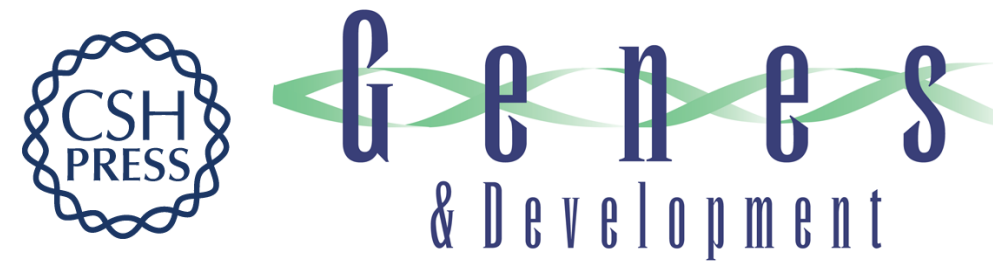

\section{Tissue-specific RNA splicing generates an ankyrin-like domain that affects the dimerization and DNA-binding properties of a bHLH protein.}

E S Klein, D M Simmons, L W Swanson, et al.

Genes Dev. 1993, 7:

Access the most recent version at doi:10.1101/gad.7.1.55

References This article cites 78 articles, 34 of which can be accessed free at:

http://genesdev.cshlp.org/content/7/1/55.full.html\#ref-list-1

\section{License}

Email Alerting Service top right corner of the article or click here.

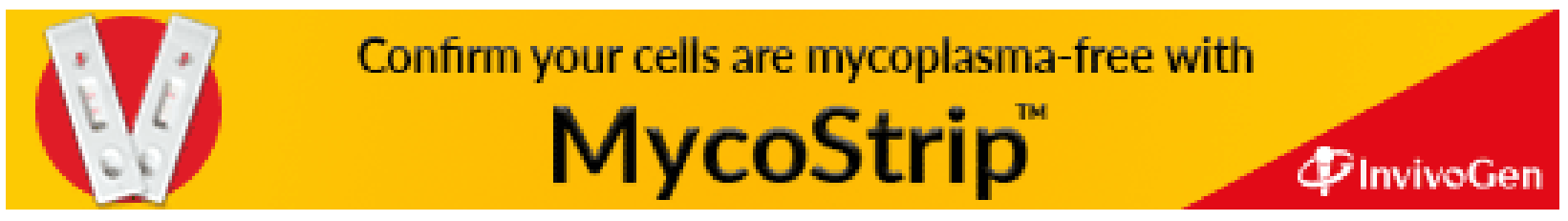

